\title{
Novel Masonry Grout Incorporating High Volumes of Industrial By-Products: Microstructure Characteristics and Pursuance of Durability Properties
}

\section{R. Ramesh Nayaka ( ramesh.nayaka@outlook.com )}

National Institute of Technology Warangal https://orcid.org/0000-0001-7563-986X

\section{U. Johnson Alengaram}

University of Malaya Faculty of Engineering

Mohd Zamin Jumaat

University of Malaya Faculty of Engineering

Rathish Kumar $\mathbf{P}$

National Institute of Technology Warangal

\section{Fernando S Fonseca}

Brigham Young University-Provo: Brigham Young University

\section{Sumesh M}

Karpagam Academy of Higher Education: Karpagam University

\section{Research Article}

Keywords: Masonry Grout, Palm Oil Clinker (POC), Palm Oil Clinker Powder (POCP), Lightweight Aggregate, Sustainability, SEM, XRD, and Durability

Posted Date: April 19th, 2021

DOI: https://doi.org/10.21203/rs.3.rs-394260/v1

License: (c) (1) This work is licensed under a Creative Commons Attribution 4.0 International License. Read Full License

Version of Record: A version of this preprint was published at Architecture, Structures and Construction on October 25th, 2021. See the published version at https://doi.org/10.1007/s44150-021-00012-x. 


\section{Abstract}

One solution to the high cost and scarcity of building materials is to use alternative and sustainable materials. The study presented herein developed an eco-friendly masonry grout using high volumes of palm oil clinker powder to replace cement and palm oil clinker to replace coarse aggregate. Several batches of grouts with different amounts of these materials were made to determine the technical viability of the grout. SEM and XRD analyses were conducted to investigate the microstructure characteristics of the grout, and water absorption, initial rate of absorption, sulphate attack and electrical resistivity tests were conducted to determine its durability. Compressive strength tests were conducted at different curing ages and the drying shrinkage of the grout was monitored for 180 days. The results indicate that the new grout is as good as a conventional grout but with added sustainable and economical benefits. The new grout can be used in masonry construction and can be used to alleviate the inadequate supply of affordable housing.

\section{Introduction}

Masonry is a composite material and its constitutive relationship is complex with distinguishing material properties, which are directly related to the properties of its constituents. Modern masonry has two main components: the masonry unit and mortar. Masonry grout is added to the basic system to increase bearing load capacity and reinforcement is added when the system needs to resist tensile loads.

A current common practice in masonry construction is to use hollow masonry blocks (HMB) or units due to the lightweight of the units, affordability and increased mason productivity. Although HMB masonry construction is effective in resisting compressive loads, it requires continuity between the units when the structure needs to resist lateral loads. For such cases, the structure needs to be reinforced and reinforcement requires masonry grout to bond the reinforcement to the masonry units.

Several studies have been conducted on masonry grout that contains environmentally friendly materials such as fly ash, bentonite, ground granulated steel slag, water glass [1]-[3], hydraulic lime [4]-[6], claybased grout [7], waste marble powder [8], perlite by-product [9] and metakaolin [6]. Studies on the utilisation of palm oil industrial by-products or palm oil clinker (POC) in masonry grout are, however, very limited [10] even though studies have demonstrated the highly pozzolanic reactive binding characteristics of POC [11]-[12].

POC has been proposed as a replacement for coarse aggregate to produce lightweight concrete and as supplementary cementitious material for enhancing the strength of concrete [13]-[12]. Mohammed et al. [14] replaced the coarse aggregate in concrete with POC and investigated the behaviour of slabs and the shear and flexure strengths of beams constructed with POC-concrete. The POC concrete was approximately $18 \%$ lighter than the normal concrete and the structural behaviour of the POC-concrete slab was similar to that of normal concrete slabs [14]. The failure mode of the POC-concrete beams was similar to that of conventional concrete beams without shear reinforcement [15]. Even though the 
modulus of elasticity of the POC-concrete was smaller than that of normal concrete, the crack width of POC-concrete beams was within acceptable limits. The behaviour of POC-concrete beams is essentially ductile, giving ample warning of the imminence failure [16]-[17]. Kanadasan and Razak [18] studied selfconsolidating concrete (SCC) using POC to replace the coarse aggregate at various replacement rate. The authors noticed a reduction in workability and determined a decrease in compressive and flexural strengths as the POC content increased. POC also negatively affect the elastic modulus of concrete [19]. Although there is a decrease in strength as the POC replacement rate increases [20], the strength of a $100 \%$ POC concrete is still approximately $70 \%$ of that of a conventional concrete [21]. Studies have also been conducted on using POC to evaluate engineering and sustainability performance of POC-concrete and the results indicate a positive outcome on cost reduction, reduced carbon emission, and energysaving [22]. The use of POC as fine aggregate in concrete revealed no significant effect on the compressive strength of the concrete[23]. POC has been used as $100 \%$ replacement to the fine aggregates in a flowable mortar and although the strength is $86 \%$ of that of the control group, the resistivity is $64 \%$ greater than that of the control group. Moreover, life cycle assessment showed a reduction of ecotoxicity category [24].

Ibrahim et al. [25] studied the effect of POC in pervious concrete and reported that the density and compressive strength decreased as the replacement of rate of POC increased. In contrast, the permeability and porosity increased as the replacement rate increased. Considering the advantages of the pervious concrete properties, the authors suggested that a $25 \%$ replacement is optimum. A similar study [26] was conducted and the authors reported that the abrasion resistance of pervious concrete decreased with increase POC replacement rate. Despite some small negative effects; overall, the utilization of POC in concrete has been shown to give reasonably good results and that it is suitable for many applications [27].

Industrial by-products have been incorporated in mortar, normal and lightweight concrete, selfconsolidating concrete, and fibre reinforced concrete. However, there has not been a comprehensive investigation on the effects of incorporating POC in masonry grout and there have been very few studies on evaluation of its durability properties. Such an investigation is important due to its possible contribution to the global socio-economic-environmental issue. For instance, the lower-middle-income group of many communities around the world prefer to build structures using materials that are affordable, locally available, ease to handle and to construct with, durable and requires very low maintenance. Masonry fits this material category very well and POC-masonry grout can make masonry even more attractive as a building material. This study fills an important gap in knowledge.

\section{Materials And Methodology \\ 2.1 Materials \\ 2.1.1 Binders}


The ordinary Portland cement (OPC) grade 42.5, which met the specifications of ASTM C150-14 [28], was used for the production of masonry grout. POC was procured from local palm oil industry and processed to powder (POCP) as described by Nayaka et al. [29]. The physical properties of the OPC and POCP are summarized in Table 1 while their gradations are shown in Fig. 1. The OPC and POPC particles were heavier than water and the POCP particles were about $20 \%$ lighter than that of the OPC because of their amount of micropores. The fineness of binders and mineral admixtures are vital as they can modify the aggregate-paste weakest part, i.e., the interfacial transition zone (ITZ) [30]. The amount of nonevaporable water and presence of unburnt carbon in binders, which could influence hydration, was measured based on LOI. The LOI of POCP was about $5.23 \%$, which was 2.6 times more than that of OPC although it is within the limit of $12 \%$ in accordance with ASTM C618-14 [28].

Table 1

Physical properties of binders

\begin{tabular}{|lll|}
\hline Properties & OPC & POCP \\
\hline Specific gravity & 3.15 & 2.55 \\
\hline Blain's specific surface Area $\left(\mathrm{m}^{2} / \mathrm{kg}\right)$ & 346 & 210 \\
\hline LOI & 2.01 & 5.23 \\
\hline D50 $(\mu \mathrm{m})$ & 28.20 & 47.85 \\
\hline
\end{tabular}

The chemical composition of the OPC and POCP is presented in Table 2. The POCP was rich in silica, with a content of approximately $60 \%$. The $\mathrm{SiO}_{2}+\mathrm{Al}_{2} \mathrm{O}_{3}+\mathrm{Fe}_{2} \mathrm{O}_{3}$ (SAF) content of the POCP was approximately $71 \%$. POCP can be classified as a Class-F pozzolan material, which contains a minimum amount of SAF of $70 \%$, a maximum amount of $\mathrm{SO}_{3}$ of $5 \%$, and LOI of less than $10 \%$ [31]. Additionally, the soluble contents of silica and alumina in POCP were within the requirements of ASTM C618-14 [31]. These oxides are the primary contributors to the strength and strength gain of the binder paste [32]. 
Table 2

Chemical composition of

binders

\begin{tabular}{|lll|}
\hline Oxides (\%) & OPC & POCP \\
\hline $\mathrm{SiO}_{2}(\mathrm{~S})$ & 16.86 & 60.29 \\
$\mathrm{Al}_{2} \mathrm{O}_{3}(\mathrm{~A})$ & 3.83 & 5.83 \\
$\mathrm{Fe}_{2} \mathrm{O}_{3}(\mathrm{~F})$ & 3.76 & 4.71 \\
\hline $\mathrm{SAF}$ & & 70.83 \\
$\mathrm{CaO}$ & 68.14 & 3.28 \\
$\mathrm{MgO}$ & 2.04 & 4.2 \\
\hline $\mathrm{P}_{2} \mathrm{O}_{5}$ & 0.04 & 3.78 \\
\hline $\mathrm{K}_{2} \mathrm{O}$ & 0.21 & 7.24 \\
\hline $\mathrm{SO}_{3}$ & 4.84 & 0.31 \\
\hline $\mathrm{TiO}_{2}$ & 0.14 & 0.1 \\
\hline $\mathrm{MnO}$ & 0.11 & 0.12 \\
\hline $\mathrm{Na}_{2} \mathrm{O}$ & 0.03 & 0.2 \\
\hline
\end{tabular}

\subsubsection{Normal Consistency and Time of Setting}

The normal consistency and time of setting were determined for a control paste that had only OPC and for a binary paste that had a combination of 70\% OPC and 30\% POCP. The normal consistency test determined the amount of water for the paste to become plastic; initial setting time established the time between the addition of water to the binder and loss of plasticity of the paste, and final setting time established the time between the addition of water to the binder and attainment of firmness of the paste to resist pressure. The results of the normal consistency tests and the time of setting for the two pastes are presented in Table 3. The OPC-POCP binary paste required more water than the OPC paste to attain normal consistency, i.e., become plastic, can be due to lower density of POCP produces greater paste volume which in turn increases the plasticity of paste[33]. The binary paste attained normal consistency with approximately $22 \%$ more water than the OPC paste and the initial and final setting times were delayed by 40 and 72 minutes, respectively, from that obtained for the OPC paste. The observation of delaying setting times in binary mix might be due to the combined effect of lower cement content[34]. Nevertheless, the determined initial and final setting times for the binary paste were within the limits set forth by ASTM C191-14 [35]. 
Table 3

Normal consistency and setting times of binders paste

\begin{tabular}{|llll|}
\hline Binders & $\begin{array}{l}\text { Normal Consistency } \\
(\%)\end{array}$ & $\begin{array}{l}\text { Initial Setting Time } \\
\text { (Minutes) }\end{array}$ & $\begin{array}{l}\text { Final Setting Time } \\
\text { (Minutes) }\end{array}$ \\
\hline OPC & 32 & 70 & 335 \\
\hline $\begin{array}{l}70 \% \text { OPC }+30 \% \\
\text { POCP }\end{array}$ & 38 & 110 & 407 \\
\hline
\end{tabular}

\subsubsection{Fine and Coarse Aggregates}

Locally available natural sand (N-Sand) was used in the control masonry grout (GC), and in the grouts of phase I; manufactured sand (M-Sand) was used in the grouts of phase II GC(M). POC, shown in Fig. 2, was used as coarse aggregate in lieu of granite in the grouts of phase II. The gradations and particle size distributions of the fine and coarse aggregates are shown in Fig. 3. The size distribution of the aggregates is within the upper and lower limits specified in ASTM C404-14 [36].

The specific gravity, water absorption, moisture content, bulk density, and fineness modulus of the fine and coarse aggregates were also determined. The fine and coarse aggregates were tested according with the specification on ASTM C128-14 [37] and ASTM C136-14 [38], respectively. The physical properties of aggregates are presented in Table 4 . The fineness moduli of the natural and manufactured sands were 2.60 and 2.80, respectively. The fineness moduli of the granite and POC were 5.95 and 5.89, respectively.

Table 4

Physical properties of aggregates

\begin{tabular}{|c|c|c|c|c|}
\hline \multirow[t]{2}{*}{ Properties } & Granite & POC & \multirow[t]{2}{*}{ N-Sand } & \multirow[t]{2}{*}{ M-Sand } \\
\hline & \multicolumn{2}{|c|}{$(5-10 \mathrm{~mm})$} & & \\
\hline Specific gravity (SSD) & 2.65 & 1.81 & 2.57 & 2.65 \\
\hline Water absorption (\%) & 0.2 & 1.09 & 1.98 & 1.65 \\
\hline Moisture content (\%) & 0.25 & 0.55 & 0.60 & 0.25 \\
\hline Fineness Modulus & 5.95 & 5.89 & 2.60 & 2.80 \\
\hline Bulk density $\left(\mathrm{kg} / \mathrm{m}^{3}\right)$ & 1429 & 852 & 1604 & 1678 \\
\hline Aggregate crushing value (ACV) (\%) & 24.88 & 43.71 & - & - \\
\hline Aggregate impact value (\%) & 16.21 & 39.05 & & \\
\hline Angularity Number & 8 & 11 & - & - \\
\hline
\end{tabular}

\subsubsection{Water and Admixture}

Potable tap water was used for the preparation of the masonry grout. The polycarboxylate-based superplasticizer Sika ViscoCrete-2055, which has high workability with excellent slump retention, was 
used as an admixture. The dosage used was $1.6 \%$ by weight of the binder.

\subsection{Methodology}

A coarse masonry grout was selected in accordance with ASTM: C476-14 [39], which is preferable to minimize cost and shrinkage and suitable for infilling of masonry structural elements such as reinforced bond beams and masonry columns. A mix proportion of 1:03:02 (Cement: fine aggregate: coarse aggregate) was selected and the proportion of ingredients was calculated in accordance with $\mathrm{ACI} 211.2-$ 98 [40]. The study was divided into three phases. In phase I, POCP was used to replace up to 50\% of OPC.

In phase I, there were 6 mixes: 1 control mix with $100 \%$ OPC and 5 binary mixes with different combinations of POCP-OPC. In phase II, POC was used to replace the coarse aggregate up to $100 \%$ of the grout mix GB3 from phase I. In phase II there were 5 mixes: 1 control mix with $100 \%$ of granite and 4 binary mixes with different combinations of granite-POC. In phase III, the binary mix GBP2 from phase II was considered for further investigation and comparison to the control grout of phase l; both mixes were modified using a superplasticizer and consolidated using a mechanical vibrator. Since this was a comparative study, instead of the absorbent masonry mould described in ASTM C1019-14[41], the specimens were cast in steel moulds. The test matrices for phases I, II, and III are presented in Table 5, Table 6, Table 7, respectively.

Table 5

Masonry grout mix proportions for Phase I

\begin{tabular}{|lllllll|}
\hline $\begin{array}{l}\text { Mix } \\
\text { ID }\end{array}$ & $\begin{array}{l}\text { POCP } \\
\text { Replacement } \\
(\%)\end{array}$ & $\begin{array}{l}\text { OPC } \\
\left(\mathbf{k g} / \mathrm{m}^{3}\right)\end{array}$ & $\begin{array}{l}\text { POCP } \\
\left(\mathbf{k g} / \mathrm{m}^{3}\right)\end{array}$ & $\begin{array}{l}\text { N-Sand } \\
\left(\mathbf{k g} / \mathrm{m}^{3}\right)\end{array}$ & $\begin{array}{l}\text { Granite } \\
\left(\mathbf{k g} / \mathrm{m}^{3}\right)\end{array}$ & $\begin{array}{l}\text { w/b } \\
\text { ratio }\end{array}$ \\
\hline GC & 0 & 230 & 0 & 692 & 487 & 0.84 \\
\hline GB1 & 10 & 207 & 23 & 692 & 487 & 0.84 \\
\hline GB2 & 20 & 184 & 46 & 692 & 487 & 0.85 \\
\hline GB3 & 30 & 161 & 69 & 692 & 487 & 0.85 \\
\hline GB4 & 40 & 138 & 92 & 692 & 487 & 0.86 \\
\hline GB5 & 50 & 115 & 115 & 692 & 487 & 0.86 \\
\hline
\end{tabular}


Table 6

Masonry grout mix proportions for Phase II

\begin{tabular}{|c|c|c|c|c|c|c|c|c|}
\hline \multirow[t]{2}{*}{ Mix ID } & \multicolumn{2}{|c|}{$\begin{array}{l}\text { Replacement } \\
(\%)\end{array}$} & \multirow[t]{2}{*}{$\begin{array}{l}\text { OPC } \\
\left(\mathrm{kg} / \mathrm{m}^{3}\right)\end{array}$} & \multirow[t]{2}{*}{$\begin{array}{l}\text { РOCP } \\
\left(\mathrm{kg} / \mathrm{m}^{3}\right)\end{array}$} & \multirow[t]{2}{*}{$\begin{array}{l}\text { M-Sand } \\
\left(\mathrm{kg} / \mathrm{m}^{3}\right)\end{array}$} & \multirow[t]{2}{*}{$\begin{array}{l}\text { Granite } \\
\left(\mathrm{kg} / \mathrm{m}^{3}\right)\end{array}$} & \multirow[t]{2}{*}{$\begin{array}{l}\text { POC } \\
\left(\mathrm{kg} / \mathrm{m}^{3}\right)\end{array}$} & \multirow[t]{2}{*}{$\begin{array}{l}w / b \\
\text { ratio }\end{array}$} \\
\hline & POCP & POC & & & & & & \\
\hline $\mathrm{GC}(\mathrm{M})$ & - & - & 230 & 00 & 762 & 487 & - & 0.82 \\
\hline GB3 & 30 & 000 & 161 & 69 & 692 & 487 & - & 0.85 \\
\hline GBP1 & 30 & 025 & 161 & 69 & 762 & 365 & 072 & 0.86 \\
\hline GBP2 & 30 & 050 & 161 & 69 & 762 & 243 & 144 & 0.86 \\
\hline GBP3 & 30 & 075 & 161 & 69 & 762 & 122 & 215 & 0.88 \\
\hline GBP4 & 30 & 100 & 161 & 69 & 762 & 000 & 287 & 0.92 \\
\hline
\end{tabular}

Table 7

Masonry grout mixtures proportions for phase III

\begin{tabular}{|llllllllll|}
\hline $\begin{array}{l}\text { Mix } \\
\text { ID }\end{array}$ & $\begin{array}{l}\text { Replacement } \\
(\%)\end{array}$ & OPC & $\begin{array}{l}\text { POCP } \\
\left(\mathrm{kg} / \mathrm{m}^{3}\right)\end{array}$ & $\begin{array}{l}\text { M-Sand } \\
\left(\mathrm{kg} / \mathrm{m}^{3}\right)\end{array}$ & $\begin{array}{l}\text { Granite } \\
\left(\mathrm{kg} / \mathrm{m}^{3}\right)\end{array}$ & $\begin{array}{l}\text { POC } \\
\left(\mathbf{k g} / \mathrm{m}^{3}\right)\end{array}$ & w/b & $\begin{array}{l}\text { SP } \\
(\%)\end{array}$ \\
\cline { 2 - 4 } & POCP & POC & $\left(\mathrm{kg} / \mathrm{m}^{3}\right)$ & & & & & & \\
\hline GC & 0 & 0 & 230 & 0 & 692 & 487 & 0 & 0.6 & 1.6 \\
\hline GBP & 30 & 50 & 161 & 69 & 762 & 243 & 144 & 0.6 & 1.6 \\
\hline
\end{tabular}

The compressive strengths of the grouts in Phases I and II were determined at the age of 3, 7, 28, and 56 days. The specimens in these phases were cured in water. The compressive strengths of the grouts in phase III were evaluated at 7, 28, 56, and 90 days. The specimens in phase III were cured in water and air.

Durability properties were determined for the control and the GBP2 i.e. GBP mixes only. The water absorption of the grouts by immersion and capillary action were determined at 28 days. The sulphate resistance of the grouts was studied by using a $5 \%$ concentration of $\mathrm{MgSO}_{4}$ solution at 28,90 , and 120 days. The electrical resistivity of the grouts was determined at 7, 14,28 , and 56 days. Some specimens were cured in water for 72 hours to study drying shrinkage, and shrinkage values were obtained for a period of up to 180 days. The details of the tests and reference standards followed in this study is summarized in Table 8. 
Table 8

Details of tests, reference standards and properties determined for masonry grout

\begin{tabular}{|c|c|c|c|c|c|}
\hline $\begin{array}{l}\text { S. } \\
\text { No. }\end{array}$ & Test & $\begin{array}{l}\text { Reference } \\
\text { Standard }\end{array}$ & $\begin{array}{l}\text { No. of } \\
\text { Samples }\end{array}$ & $\begin{array}{l}\text { Type and Size of } \\
\text { Specimens }(\mathrm{mm})\end{array}$ & Properties \\
\hline \multirow[t]{2}{*}{1} & Preparation of specimens & $\begin{array}{l}\text { ASTM } \\
\text { C1019-14 }\end{array}$ & \multirow[t]{3}{*}{-} & \multirow[t]{3}{*}{-} & \multirow[t]{3}{*}{ Fresh State } \\
\hline & and curing & $\begin{array}{l}\text { ASTM } \\
\text { C511-14 }\end{array}$ & & & \\
\hline \multirow[t]{2}{*}{2} & Slump cone test & $\begin{array}{l}\text { ASTM } \\
\text { C143-14 }\end{array}$ & & & \\
\hline & Hardened density & $\begin{array}{l}\text { ASTM } \\
\text { C642-14 }\end{array}$ & \multirow[t]{3}{*}{3} & \multirow{3}{*}{$\begin{array}{l}\text { Cube } \\
100 * 100 * 100\end{array}$} & \multirow[t]{3}{*}{ Mechanica } \\
\hline 3 & Compressive strength & $\begin{array}{l}\text { BS EN } \\
12390-3: \\
2009\end{array}$ & & & \\
\hline 4 & Ultrasonic pulse velocity & $\begin{array}{l}\text { ASTM } \\
\text { C597-14 }\end{array}$ & & & \\
\hline \multirow[t]{2}{*}{8} & \multirow{2}{*}{$\begin{array}{l}\text { Bulk and apparent density, } \\
\text { water absorption by } \\
\text { immersion }\end{array}$} & \multirow{2}{*}{$\begin{array}{l}\text { ASTM } \\
\text { C642-14 }\end{array}$} & \multirow[t]{2}{*}{3} & \multirow{4}{*}{$\begin{array}{l}\text { Cube } \\
100 * 100 * 100\end{array}$} & \multirow[t]{6}{*}{ Durability } \\
\hline & & & & & \\
\hline 9 & Water absorption by capillary & $\begin{array}{l}\text { ASTM } \\
\text { C1585-14 }\end{array}$ & 3 & & \\
\hline 10 & $\begin{array}{l}\text { Resistance to sulphate } \\
\text { solution }\end{array}$ & $\begin{array}{l}\text { ASTM } \\
\text { C157-14 }\end{array}$ & 3 & & \\
\hline \multirow[t]{2}{*}{11} & \multirow[t]{2}{*}{ Electrical resistivity } & \multirow{2}{*}{$\begin{array}{l}\text { ASTM } \\
1202-14\end{array}$} & \multirow[t]{2}{*}{3} & Prism & \\
\hline & & & & $70 * 70 * 300$ & \\
\hline \multirow[t]{2}{*}{12} & \multirow[t]{2}{*}{ Drying shrinkage } & \multirow{2}{*}{$\begin{array}{l}\text { ASTM } \\
\text { C596-14 }\end{array}$} & \multirow[t]{2}{*}{5} & Prism & \multirow{2}{*}{$\begin{array}{l}\text { Time- } \\
\text { Dependent }\end{array}$} \\
\hline & & & & $70 * 70 * 300$ & \\
\hline
\end{tabular}

\section{Results And Discussions}

\subsection{Microstructure Characteristics}

The SEM images of the control and binary, i.e., 30\% POCP + 70\% OPC + 50\% POC (GBP) grouts cured in water (GCW and GBPW) and cured in magnesium sulphate (GCS and GBPS) for 28 days are shown in Fig. 4.

The higher silica and calcium correspond to the binder and POC aggregate. In the grouts cured in water (images GCW and GBPW), the tricalcium silicate hydrates with water to form a dense acicular calcium silicate hydrate $(\mathrm{C}-\mathrm{S}-\mathrm{H})$ and hexagonal calcium hydroxide $(\mathrm{CH})$ crystal along with the formation of 
capillary pores and voids. The sulphate-cured grouts (images GCS and GBPS) had alumina silicate (AS), calcium silicate (CS) and silica, besides the presence of gypsum and brucite.

The analysis of the grouts cured in the magnesium sulfate solution showed that the binary grout paste was denser than that of the control grout because of the irregular shape and rough surface texture of the POC, which induces stronger bond between the aggregates and paste [42]. However, GBPW grout in Fig. 4, was observed the loss of moisture results in shrinkage cracks. The loss of moisture due to moisture absorption at the interface with underlying materials[43].

The GBP grout had large crystals of $\mathrm{CH}$ and mono-sulphoaluminate [44]. However, only a limited amount of acicular C-S-H was observed due to delay in the reaction of the di-calcium silicates. Also, spherical dense and partially dense ettringite were observed in the binary grout cured in the sulphate solution due to the presence of $\mathrm{SO}_{3}$, which acts like gypsum and reacts with the CS crystals. There were, however, no calcium hydroxide plates in both sulphate solution cured GBP grouts although the ratio of $\mathrm{MgO}$ to $\mathrm{Fe}_{2} \mathrm{O}_{3}$ of 1.06 is well within the limit to avoid expansion [45].

An X-ray diffraction (XRD) analysis was conducted for the control and binary grouts cured in air (AC), water (WC) and sulphate (SC) for 28 and 120 days. The XRD patterns are shown in Fig. 5 at the end of the 28-day curing.

High portlandite $(\mathrm{CH})$ peaks were observed for the GC grouts cured in water, which indicates the presence of excess moisture that caused delays in the conversion of the silicates to $\mathrm{C}-\mathrm{S}-\mathrm{H}$ and $\mathrm{CH}$ for strength development. In contrast, the $\mathrm{CH}$ peaks were smaller for the grouts cured in air and sulphate. For the $\mathrm{GB}$ grouts, the air-cured specimen had high peaks of portlandite; parallel cristobalite peaks were also observed. Similar pattern has been observed for fly ash and rice husk ash [46]. A high cristobalite peak was observed for the GB grout cured in the sulphate solution, which could be due to the presence of silica in the POCP and the reaction with the sulphate solution to form gypsum.

\subsection{Workability and fresh state density}

The total water to total binder (cementitious materials) ratio $(\mathrm{w} / \mathrm{b})$, the POCP and POC replacement levels, in phase I and II, the fresh state density obtained to meet the required consistency (204 mm - $280 \mathrm{~mm})$ for the grouts are shown in Fig. 6.

In phase I, the $\mathrm{w} / \mathrm{b}$ ratio for the control grout $(\mathrm{GC})$ was 0.84 , while binary grouts with POCP (GB1 through GB5) had $w / b$ ratios between 0.84 and 0.86 . The $w / b$ ratio increased with increasing POCP replacement level, which could be attributed to the presence of unburnt carbon, moderately coarse texture, irregular particle shape and sharp edges of the POPC [47]. On the other hand, the specific gravity of the grouts decreased with increasing POCP levels. The decrease in specific gravity was expected since POPC has lower specific gravity than OPC; the decrease should have been linear since the replacement rate used herein was linear. 
As observed for the binary grouts in phase I, the binary grouts in phase II experienced an increase in water demand and a decrease in density as the amount of POC increased. To attain the required consistency, the POC-incorporated grout mixes required up to $9 \%$ more water than that required in the control mix due to the irregular shape, porosity, and higher water absorption of POC [48].

The grouts with POC had greater slump than that of the control grout due to the lower density [49] and better-rolling capability of the POC [50]. The binary grout with 30\% POCP and 50\% POC was considered an ideal mix based on the fresh state density and minimal presence of voids according to the ASTM C476-14 [39] requirement of compressive strength.

In phase - III, a superplasticizer (SP) was used to reduce the water demand and increase the workability, due to greater surface and dispersion properties of the SP [51], of the binary grout with $30 \%$ POCP and $50 \%$ POC and of the control grout. The fresh properties of this SP-modified binary grout and the SPmodified control grout are presented in Table 9. To minimize the variables and eliminating confounding results, the same $\mathrm{w} / \mathrm{b}$ ratio and the same SP percentage were used in both mixes.

Table 9

Fresh state properties of control and ideal grout mixes

\begin{tabular}{|llllllc|}
\hline Mix ID & \multicolumn{2}{l}{ Replacement (\%) } & w/b ratio & Fresh State Density $\left(\mathrm{kg} / \mathrm{m}^{3}\right)$ & Slump (mm) & S.P (\%) \\
\cline { 2 - 4 } & POCP & POC & & & 22 & \\
\hline GC & 0 & 0 & 0.6 & 2470 & 228 & 1.6 \\
\hline GBP & 30 & 50 & 0.6 & 2382 & 216 & 1.6 \\
\hline
\end{tabular}

\subsection{Mechanical Properties of the Grouts}

\subsubsection{Structural Efficiency}

The definition of structural efficiency (SE) was introduced for the comparison of control specimens with GBP samples [49]. The SE value was determined by compressive strength over the hardened density of masonry grout mixes of water and air-cured for 28 days as shown in Fig. 7. In Phase I, SE decreased from 0.0107 to 0.0066 in order to replace cement by POCP up to 50 percent. When the substitution of POCP increased, the SE decreased due to weak bonding between cement and POCP molecules[12]. POCP has been shown to be a pozzolanic material because the dilution effects did not produce good bonding at higher volume substitution and because of the delay in the pozzolanic reaction, or POCP acts as filler material.

The air-cured specimens obtained higher SE values than the water-cured specimen due to the higher water content used to achieve the necessary slump value, which caused early hydration reactions. In phase II, a higher SE was found for the control mix in which M-sand was used to substitute N-sand in order to prevent the loss of natural resources. SE decreased from 0.0106 to 0.006 when POCP was used as a binder to replace $30 \%$ of cement and $\mathrm{M}$-sand was used as a sustainable material. In comparison, 
POC substitution for granite varied from 0 to 100 per cent. The decrease in SE was attributed to the fact that the porous POC aggregates caused the specimens to fail, while in the case of granite the failure happened in the interfacial region between the paste and the aggregates. In phase III, control (GC) and ideal mix grout (GPP) had SE value of 0.0169 and 0.0139 respectively when water cured. The air-cured specimens had SE values of 0.0174 for control and 0.0147 for ideal grout mix. There was a $37-46 \%$ enhancement of SE from phase II to phase III due to the influence of admixture used to improve workability and reduce water demand. Another reason is the use of mechanical vibration on masonry grout mixes.

\subsubsection{Ultrasonic pulse velocity (UPV)}

UPV presents the pulse rate transfer through solid media, and this rate is indirectly related to voids present in the specimen. The UPV method was used to determine the denseness of the control grout and the binary grout with POC aggregate. The UPV measurements on the control and binary grouts are shown in Fig. 11; the measured UPV in the control and binary specimens cured in air for 28 days were $4.42 \mathrm{~km} / \mathrm{s}$ and $3.81 \mathrm{~km} / \mathrm{s}$, respectively. The UPV values of air-cured specimens were greater than those of watercured specimens at all durations of curing. As aforementioned, the air-cured specimens had slightly higher compressive strength than that of the water-cured specimens (because curing stopped at 90 days, a longer curing period would most likely reverse the trend).

The results indicate that the presence of moisture, honeycombed POC particles, and type of aggregates influenced the UPV values. According to Malhotra [52] excellent UPV values are greater than $4.5 \mathrm{~km} / \mathrm{s}$ while good UPV values are between 3.5 and $4.5 \mathrm{~km} / \mathrm{s}$. Most measurements felt in the good category, including that for the control grout. For the binary grout, the increase in the UPV values from 28 to 90 days of curing was significant and was due to the increase in the POCP pozzolanic activity and filling of the voids in the POC aggregate. Thus, in the long term, replacing cement by POCP and granite by POC will have no negative effects on the quality of the grout.

The relationship between the compressive strength and the UPV obtained herein is shown in Fig. 12 and

given by Eq. 1 . The high $\mathrm{R}^{2}$ value indicates an excellent fit of the equation to the experimental data. Using Eq. 1, the compressive strength of grouts can be obtained using the non-destructive UPV method.

\subsection{Durability performance of masonry grout}

The durability performance of the grouts was determined by testing samples of the control grout and binary grout with POC aggregate.

\subsubsection{Densities and water absorption}

The results of the densities and water absorption tests are shown in Table 10. The densities of the binary grout were lower than that of the control mixes due to the lower specific gravity of POCP and POC while the water absorption of the binary grouts was higher because of the porosity of the POC and POCP, which 
weakens the interfacial transition zone. As aforementioned, the rough texture and porous microstructure of the POCP and POC particles [53] compromise the compactness of the grout mix. The higher water absorption of the POC was expected since lightweight aggregates generally have higher water absorption [54]. Overall, however, all masonry grout specimens in this study are well within the limit of concrete quality specified by Neville [55].

Table 10

Densities and water absorption properties of masonry grout

\begin{tabular}{|c|c|c|c|c|c|c|}
\hline $\begin{array}{l}\text { Curing } \\
\text { Age } \\
\text { (Days) }\end{array}$ & $\begin{array}{l}\text { Mix } \\
\text { ID }\end{array}$ & $\begin{array}{l}\text { Water } \\
\text { absorption (\%) } \\
(24 \text { h) }\end{array}$ & $\begin{array}{l}\text { Water } \\
\text { absorption (\%) } \\
\text { (48 h) }\end{array}$ & $\begin{array}{l}\text { Density } \\
(\text { Dry) } \\
\left(\mathrm{kg} / \mathrm{m}^{3}\right)\end{array}$ & $\begin{array}{l}\text { Density } \\
(\mathrm{SSD}) \\
\left(\mathrm{kg} / \mathrm{m}^{3}\right)\end{array}$ & $\begin{array}{l}\text { Apparent } \\
\text { Density } \\
\left(\mathrm{Mg} / \mathrm{m}^{3}\right)\end{array}$ \\
\hline \multirow[t]{2}{*}{28} & $\mathrm{GC}$ & 4.62 & 4.68 & 2304 & 2417 & 2448 \\
\hline & GBP & 4.71 & 4.79 & 2146 & 2250 & 2301 \\
\hline \multirow[t]{2}{*}{90} & $\mathrm{GC}$ & 4.90 & 5.08 & 2287 & 2431 & 2485 \\
\hline & GBP & 5.93 & 6.01 & 2140 & 2251 & 2298 \\
\hline
\end{tabular}

\subsubsection{Initial rate of water absorption}

The rates of water absorption of the grout mixes were also determined by capillary testing, and the values obtained were different from that of the immersion testing due to the internal microstructures and interfacial transitional zone. The capillary test determined the initial absorption and the secondary absorption until a constant mass, i.e., a mass variation of less than $0.5 \%$, was obtained for two consecutive periods of weighing. The results of the test are presented in Fig. 13.

The initial rate of water absorption (IRA) by capillary action of the binary grout was slightly higher than that of the control grout because of poor interlocking bonds within the POCP and POC aggregate, which causes high porosity and increases absorption. The secondary rate of absorption of the GBP grout was, however, lower as compared to that of the control. Generally, utilisation of POCP tends to improve the filling effect of grout which improves the rate of absorption at a later stage [12]. The replacement of gravel with $50 \%$ POC resulted in greater compactness due to rough surface texture, which leads to lower secondary water absorption after initial absorption at the transitional zone can be observed in Fig. 18, which is in agreement with previous studies [56]. Furthermore, lower paste strength results in higher permeability [55].

\subsubsection{Resistance to magnesium sulphate solution}

Sulphate attack is a chemical breakdown mechanism in which sulphate ions attack components of the binder paste. In this study, $5 \%$ of magnesium sulphate solution was used. Magnesium sulphate is an alkaline solution capable of reacting with the components of the masonry grout. The addition of POCP, a pozzolanic admixture, reduced the $\mathrm{C}_{3} \mathrm{~A}$ content of the paste; therefore, there was a possibility that the paste was susceptible to sulphate attack. The changes in compressive strength and weight of the grouts 
are shown in Fig. 14 and Fig. 15, respectively, when the grouts are exposed to magnesium sulphate solution for a period of 28,90 , and 120 days. In Fig. 14, the change in compressive strength is shown relative to compressive strength obtained when the grouts were cured in water. In Fig. 15, the change in weight is shown relative to the weight determine when the grouts were cured in magnesium sulfate.

After 28 days of curing, the compressive strength of the control and binary grouts improved approximately 2 to $5 \%$. The improvement could be because of the chemical reaction (combination) between the sulphate ions and C-S-H and because the sulphate ion crystals occupied the empty spaces and continue to form chemical structures that cause the paste to expand and crack. After 90 days of curing, a reduction of approximately $0.5 \%$ and $2 \%$ in compressive strength were observed for the control and binary grouts, respectively, which indicates that ettringite compounds were formed. The strength was decreased due to the highly porous nature of POC with immense macro and microvoids. Moreover, this increased void ratio in the grout to allow quick crack propagation as well as failing rapidly under applied load[57]. The changes in strength were more significant in unexposed dry-cured samples than in exposed samples. This trend was continued for 120 days exposure, there was a reduction in compressive strength of the control grout more than that of the binary grout, which could be attributed to the delayed pozzolanic reaction of POCP binder and the gypsum in the GBP mix controlling the sulphate ions to further form brucite and ettringite. An increase in $\mathrm{C}_{3} \mathrm{~S}$ content and reduction of $\mathrm{C}_{3} \mathrm{~A}$ content generate large amounts of $\mathrm{CH}$ that reacts directly with sulphate ions and are seen as a rust coating on the aggregates in the internal structure of the samples. The pores and bonding between the aggregates and the binder paste were visible for the grouts cured in air, water and sulphate solution at 120 days. This leads to the formation of gypsum and brucite, in which the portlandite peaks appear in the sulphate exposed samples.

After 28 days of curing, the weight of the control and GBP grouts increased by approximately 0 to $1.67 \%$. The sulphate ion in the space in control (GC) paste does not dry completely and hence there is no significant reduction in mass, although almost the same mass was observed in the exposed binary (GBP) mix.

Overall, this causes a reduction in the cohesiveness of the hydrated cement. Thus, sulphate attack results in the decrease of the mechanical properties and durability of the grout by changing the chemical nature of binder paste [58]. The sulphate resistance of the binary grout compared to that of the control grout is noteworthy at 120 days of exposure (can be seen in Fig. 18).

The XRD patterns for the control and GBP grouts are shown in Fig. 16 and Fig. 17, respectively, for the grouts cured in air and in a sulphate solution for 120 days. For the control grouts cured in air and water, the peaks of portlandite were converted to calcite and C-S-H gel formation, and alite and belite compounds formed at scattering angles of $18^{\circ}$ and $21^{\circ}$. The alite and belite peaks observed in the binary paste were lower than that of the control paste. In the binary paste, ettringite and brucite formations were observed and are due to the sulphate solution penetration and reaction. The conversion of portlandite to C-S-H was slow in the binary grout cured in water but it was fast in the control grout cured in water. The 
sulphate treated binary grouts had smaller portlandite peak than that of the control grout cured in the sulphate solution. The ettringite peaks were higher in the control paste than that in the binary paste, indicating the delay in pozzolanic reaction.

\subsubsection{Electrical resistivity}

The electrical resistivity of a specimen gives an indication of the ability of the specimen to resist chloride ion penetration. The electrical resistivity of the control and binary grouts cured in water for 7, 28, 56 and 90 days were determined according to AASHTO [59]. The results are presented in Fig. 15 and all values obtained, except for those for the grouts cured for 7 days, are well above the threshold value of $12 \mathrm{~K} \Omega \mathrm{cm}$ [59]. The measurements show that the chloride ion penetrability of the control and binary grouts are below the moderate penetrability category at 28 days exposure and below the low penetrability at 90 days exposure.

The results obtained herein are in agreement with those obtained by Kanadasan and Razak [20], who showed that the binary grout resistivity was $16 \%$ higher than that of the control grout. A probable reason for the high electrical resistivity is the porous microstructure of the POC aggregates as well as the higher moisture content [61]. Aggregate sizes, however, were less than $10 \mathrm{~mm}$ and therefore formed less interfacial transition zones (ITZ), as shown in Fig. 15.

\subsubsection{Drying shrinkage}

Drying shrinkage measurements were made for up to 180 days and the results are presented in Fig. 20. The POC powder and aggregate significantly affected the drying shrinkage of the grout. A possible explanation may be the higher paste to aggregate ratio in the binary grout. In addition, lightweight aggregates normally cause higher drying shrinkage [55]. The retained water in the POC aggregate evaporates over time, which leads to increased shrinkage [62]-[63].

Although the binary grout experienced higher drying shrinkage than that of the control grout, the measured value was within the appropriate limit of 750 microns suggested in ASTM C596-01[64].

\section{Conclusions}

Experiments were conducted to determine the effect of substituting Portland cement and coarse aggregate in masonry grout by palm oil industrial by-products at different replacement rate. The hardened state density, compressive strength, and durability values are indicative of the satisfactory performance of the eco-friendly masonry grout developed herein. The following are the broad conclusions from this experiment program:

- The binary grout with POC aggregates requires more water to meet practical workability requirements; nevertheless, the use of superplasticizers can reduce the water demand and enhance the fresh state properties of the grout. 
- Although a grout with $40 \%$ POCP met the minimum required compressive strength, a grout with $30 \%$ $\mathrm{POCP}$ is suggested as the ideal grout when considering other factors.

- The use of POC as coarse aggregate reduces the compressive strength of the grout. A 50\% replacement of coarse aggregate by POC, however, still can be used since a grout with such an amount of $\mathrm{POC}$ meets the minimum required compressive strength.

- The UPV value obtained for the binary grout with POC aggregates indicates that the grouts is of "good" quality.

- Although water absorption and initial rate of water absorption properties of the binary grout with POC aggregates are slightly higher than that of a conventional grout mix, the values are within the standard limit.

- The binary grout with POC aggregates has a high resistance to sulphate attack and a moderate level of chloride ion penetrability.

- The drying shrinkage of the binary grout with POC was within the appropriate limit.

- Overall, the durability performance of the binary grout with POC aggregate is similar to that of a conventional grout with added value in terms of materials cost and carbon footprint.

- Palm oil industrial by-products, more specifically powder and clinker, can be used in masonry grout without detrimental effects.

\section{Declarations}

Acknowledgement

The research funds under Research Seed Money (RSM-P1098) Grant of National Institute of Technology (NIT), Warangal, India and the research funds under Grand Challenge Project of University of Malaya, Malaysia bearing project grant number- GC003D-2015SUS to conduct this research work are acknowledged.

Conflicts of Interest Statement

Authors have no conflicts of interest

\section{References}

1. Fonseca FS, Godfrey RC, Siggard K, "Compressive strength of masonry grout containing high amounts of class $\mathrm{F}$ fly ash and ground granulated blast furnace slag," Constr. Build. Mater., vol. 94, pp. 719-727, Sep. 2015

2. Pastor JL, Ortega JM, Flor M, López MP, Sánchez I, Climent MA (Aug. 2016) Microstructure and durability of fly ash cement grouts for micropiles. Constr Build Mater 117:47-57

3. Shamsuddoha M, Hüsken G, Schmidt W, Kühne H-C, Baeßler M, "Ternary mix design of grout material for structural repair using statistical tools," Constr. Build. Mater., vol. 189, pp. 170-180, Nov. 2018 
4. Bras A, Henriques FMA, Cidade MT, "Effect of environmental temperature and fly ash addition in hydraulic lime grout behaviour," Constr. Build. Mater., vol. 24, no. 8, pp. 1511-1517, Aug. 2010

5. Vintzileou E, Miltiadou-Fezans A, "Mechanical properties of three-leaf stone masonry grouted with ternary or hydraulic lime-based grouts," Eng. Struct., vol. 30, no. 8, pp. 2265-2276, Aug. 2008

6. Vavričuk A, Bokan-Bosiljkov V, Kramar S (May 2018) The influence of metakaolin on the properties of natural hydraulic lime-based grouts for historic masonry repair. Constr Build Mater 172:706-716

7. Silva RA, Domínguez-Martínez O, Oliveira DV, Pereira EB, "Comparison of the performance of hydraulic lime- and clay-based grouts in the repair of rammed earth," Constr. Build. Mater., vol. 193, pp. 384-394, Dec. 2018

8. Çınar M, Karpuzcu M, Çanakcı H, "The measurement of fresh properties of cement-based grout containing waste marble powder," Measurement, vol. 150, p. 106833, Jan. 2020

9. Pachta V, Papadopoulos F, Stefanidou M (May 2019) Development and testing of grouts based on perlite by-products and lime. Constr Build Mater 207:338-344

10. Nayaka RR, Alengaram UJ, Jumaat MZ, Yusoff SB, Ganasan R (May 2019) Performance evaluation of masonry grout containing high volume of palm oil industry by-products. J Clean Prod 220:12021214

11. Karim MR, Hashim H, Abdul Razak H (2016) Assessment of pozzolanic activity of palm oil clinker powder. Constr Build Mater 127:335-343

12. Kanadasan J, Razak HA (2015) Utilization of palm oil clinker as cement replacement material. Materials (Basel) 8(12):8817-8838

13. Ahmmad R, Jumaat MZ, Alengaram UJ, Bahri S, Rehman MA, H bin Hashim, "Performance evaluation of palm oil clinker as coarse aggregate in high strength lightweight concrete," J. Clean. Prod., vol. 112, pp. 566-574, Jan. 2016

14. Mohammed BS, Al-Ganad MA, Abdullahi M, "Analytical and experimental studies on composite slabs utilising palm oil clinker concrete," Constr. Build. Mater., vol. 25, no. 8, pp. 3550-3560, Aug. 2011

15. Mohammed BS, Foo WL, Hossain KMA, Abdullahi M, "Shear strength of palm oil clinker concrete beams," Mater. Des., vol. 46, pp. 270-276, Apr. 2013

16. Mohammed BS, Foo WL, Abdullahi M, "Flexural strength of palm oil clinker concrete beams," Mater. Des., vol. 53, pp. 325-331, Jan. 2014

17. Constr. Build. Mater., vol. 127, pp. 18-25, Nov. 2016

18. Kanadasan J, Razak HA, "Mix design for self-compacting palm oil clinker concrete based on particle packing," Mater. Des., vol. 56, pp. 9-19, Apr. 2014

19. Abutaha F, Abdul Razak H, Kanadasan J (2016) Effect of palm oil clinker (POC) aggregates on fresh and hardened properties of concrete. Constr Build Mater 112:416-423

20. Kanadasan J, Razak HA (2015) Utilization of Palm Oil Clinker as Cement Replacement Material. Materials (Basel) 8:8817-8838 
21. Kanadasan J, "Feasibility study of palm oil clinker as environmentally friendly self-compacting concrete," University of Malaya, 2016

22. Kanadasan J, Abdul Razak H (2015) Engineering and sustainability performance of self-compacting palm oil mill incinerated waste concrete. J Clean Prod 89:78-86

23. Kanadasan J, Razak HA, Subramaniam V (2018) Properties of high flowable mortar containing high volume palm oil clinker (POC) fine for eco-friendly construction. J Clean Prod 170:1244-1259

24. Kanadasan J, Razak HA, Subramaniam V (Jan. 2018) Properties of high flowable mortar containing high volume palm oil clinker (POC) fine for eco-friendly construction. J Clean Prod 170:1244-1259

25. Ibrahim HA, Abdul Razak H (2016) Effect of palm oil clinker incorporation on properties of pervious concrete. Constr Build Mater 115:70-77

26. Ibrahim HA, Razak HA, Abutaha F, "Strength and abrasion resistance of palm oil clinker pervious concrete under different curing method," Constr. Build. Mater., vol. 147, pp. 576-587, Aug. 2017

27. Abutaha F, Razak HA, Ibrahim HA, Ghayeb HH (2018) Adopting particle-packing method to develop high strength palm oil clinker concrete. Resour Conserv Recycl 131:247-258

28. ASTM C150-14 (2014) "Standard Specification for Portland Cement. " ASTM International, West Conshohocken

29. Nayaka RR, Alengaram UJ, Jumaat MZ, Yusoff SB, Alnahhal MF, "High volume cement replacement by environmental friendly industrial by-product palm oil clinker powder in cement - lime masonry mortar," J. Clean. Prod., vol. 190, pp. 272-284, Jul. 2018

30. Tasdemir $\mathrm{C}$, "Combined effects of mineral admixtures and curing conditions on the sorptivity coefficient of concrete," Cem. Concr. Res., vol. 33, no. 10, pp. 1637-1642, Oct. 2003

31. ASTM C618-14 (2014) "Standard Specification for Coal Fly Ash and Raw or Calcined Natural Pozzolan for Use in Concrete. " ASTM International, West Conshohocken

32. Rassineux AMF, Petit JC (1989) Ancient analogues of modern cement: calcium hydrosilicates in mortars and concretes from Gallo-Roman thermal baths of Western France. J Am Ceram Soc 72(6):1026-1032

33. Şahmaran M, Özkan N, Keskin SB, Uzal B, Yaman ï, Erdem TK, "Evaluation of natural zeolite as a viscosity-modifying agent for cement-based grouts," Cem. Concr. Res., vol. 38, no. 7, pp. 930-937, Jul. 2008

34. and Berg HK, Von W, "Fresh mortar and concrete with fly ash," aylor Fr., pp. 24-41, 1991

35. ASTM C191-14, "Standard Test Methods for Time of Setting of Hydraulic Cement by Vicat Needle," West Conshohocken, PA, 2014

36. ASTM C404-14, "Standard Specification for Aggregates for Masonry Grout," 2014

37. ASTM C128-2004, "Standard Test Method for Density, Relative Density (Specific Gravity), and Absorption of Fine Aggregate." ASTM International (2004)

38. ASTM C136-14 (2014) "Standard Test Method for Sieve Analysis of Fine and Coarse Aggregates." ASTM International, West Conshohocken 
39. ASTM C476-14, "Standard Specification for Grout for Masonry," West Conshohocken, 2014

40. ACl 211.2-98, "Standard Practice for Selecting Proportions for Structural Lightweight Concrete," New York, 1998

41. ASTM C1019-14, "Standard Test Method for Sampling and Testing Grout," West Conshohocken, 2014

42. Hong L, Gu X, Lin F, "Influence of aggregate surface roughness on mechanical properties of interface and concrete," Constr. Build. Mater., vol. 65, pp. 338-349, Aug. 2014

43. Banthia N, Gupta R, "Influence of polypropylene fiber geometry on plastic shrinkage cracking in concrete," Cem. Concr. Res., vol. 36, no. 7, pp. 1263-1267, Jul. 2006

44. Kumar PJMMMP, Concrete: microstructure, properties, and materials, Third Edit. McGraw-Hill Publishing, 2015

45. Klemm WA, "Cement Soundness and the Autoclave Expansion: Test-An Update of the Literature," 2005

46. Sua-lam G, Makul N (2014) Utilization of high volumes of unprocessed lignite-coal fly ash and rice husk ash in self-consolidating concrete. J Clean Prod 78:184-194

47. Karim MR, Hashim H, Razak HA, Yusoff S, "Characterization of palm oil clinker powder for utilization in cement-based applications," Constr. Build. Mater., vol. 135, pp. 21-29, Mar. 2017

48. Alnahhal M, Alengaram MF, Jumaat UJ, Alqedra MZ, Mo MA, K. H., \& Sumesh (2017) Evaluation of Industrial By-Products as Sustainable Pozzolanic Materials in Recycled Aggregate Concrete. Sustainability 9(5):767

49. Choi YW, Kim YJ, Shin HC, Moon HY, "An experimental research on the fluidity and mechanical properties of high-strength lightweight self-compacting concrete," Cem. Concr. Res., vol. 36, no. 9, pp. 1595-1602, Sep. 2006

50. Jegathish $\mathrm{K}$, “Feasibility study of palm oil clinker as environmentally friendly self-compacting concrete/Jegathish Kanadasan," Doctoral dissertation, University of Malaya., 2016

51. Heikal M, Zohdy KM, Abdelkreem M (Jan. 2013) Mechanical, microstructure and rheological characteristics of high performance self-compacting cement pastes and concrete containing ground clay bricks. Constr Build Mater 38:101-109

52. Malhotra VM, Testing hardened concrete: nondestructive methods. CRC Press, 1976

53. Lynn CJ, Dhir RK OBE, and Ghataora GS, "Municipal incinerated bottom ash characteristics and potential for use as aggregate in concrete," Constr. Build. Mater., vol. 127, pp. 504-517, Nov. 2016

54. Topçu IB, Uygunoğlu T, "Effect of aggregate type on properties of hardened self-consolidating lightweight concrete (SCLC)," Constr. Build. Mater., vol. 24, no. 7, pp. 1286-1295, Jul. 2010

55. Neville AM (1995) Properties of concrete, 4th edn. Longman, London

56. Dogan UA, Ozkul MH, "The effect of cement type on long-term transport properties of selfcompacting concretes," Constr. Build. Mater., vol. 96, pp. 641-647, Oct. 2015 
57. Corinaldesi V, Moriconi G, "Behaviour of cementitious mortars containing different kinds of recycled aggregate," Constr. Build. Mater., vol. 23, no. 1, pp. 289-294, Jan. 2009

58. Al-Amoudi OSB, "Performance of 15 reinforced concrete mixtures in magnesium-sodium sulphate environments," Constr. Build. Mater., vol. 9, no. 3, pp. 149-158, Jun. 1995

59. AASHTO T, "Standard Method of Test for Surface Resistivity Indication of Concrete's Ability to Resist Chloride Ion Penetration," in AASHTO Provisional Standards, 2011 Editi., 2011

60. Kanadasan J, Abdul Razak $\mathrm{H}$, "Engineering and sustainability performance of self-compacting palm oil mill incinerated waste concrete," J. Clean. Prod., vol. 89, pp. 78-86, Feb. 2015

61. Naganathan S, Razak HA, Hamid SNA, "Corrosivity and leaching behavior of controlled low-strength material (CLSM) made using bottom ash and quarry dust," J. Environ. Manage., vol. 128, pp. 637641, Oct. 2013

62. Dhir KAPRK, Dyer TD, Halliday JE, "Value added recycling of incinerator ashes," DETR Research Contract No 39/3/476 CC 1683, 2002

63. van der Wegen J, Hofstra G, U., \& Speerstra (2013) Upgraded MSWI bottom ash as aggregate in concrete. Waste Biomass Valoriz 4(4):737-743

64. A. C596-01, "Standard Test Method for Drying Shrinkage of Mortar Containing Hydraulic Cement," 2001

\section{Figures}

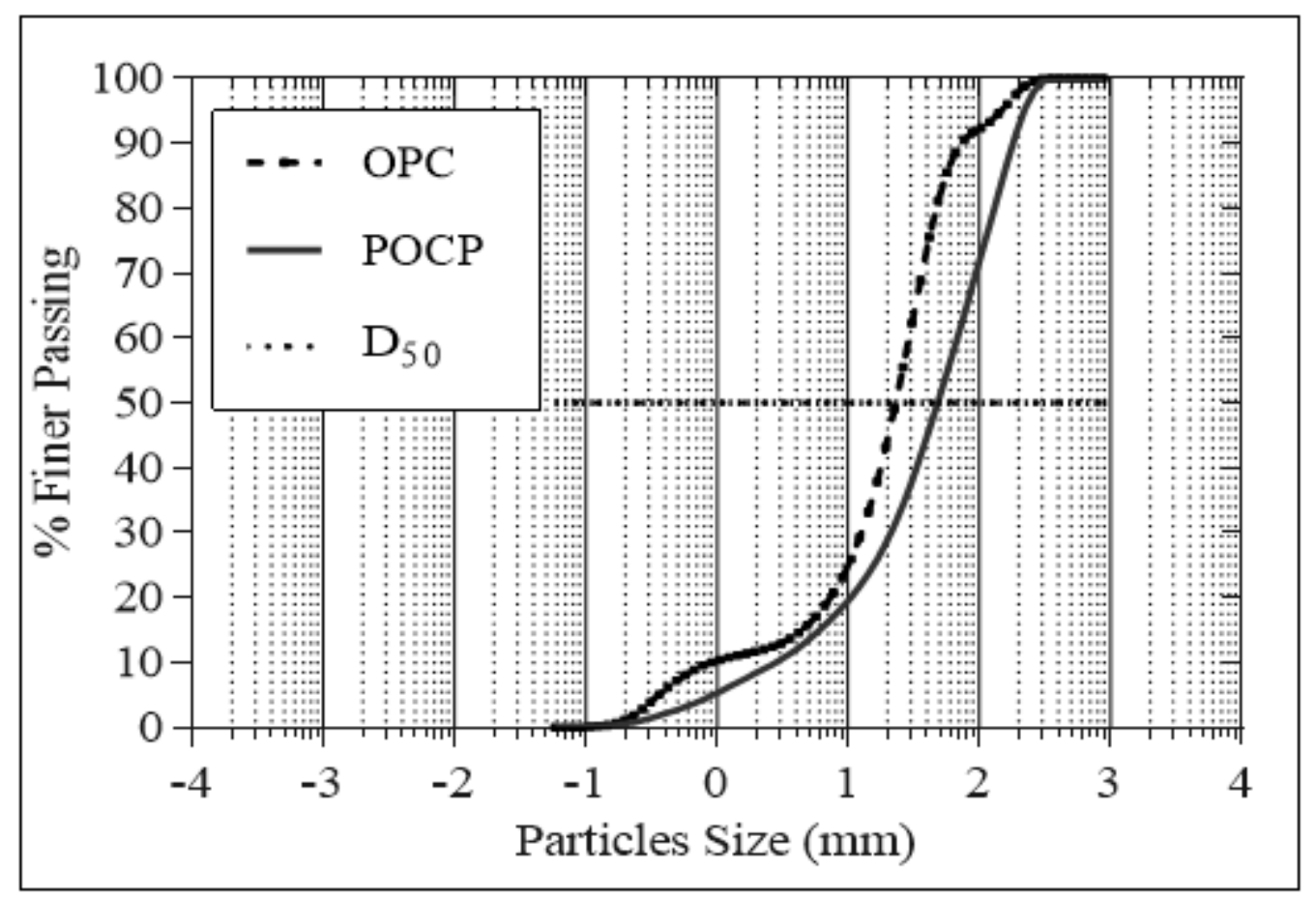

\section{Figure 1}


Grain size distribution of OPC and POCP

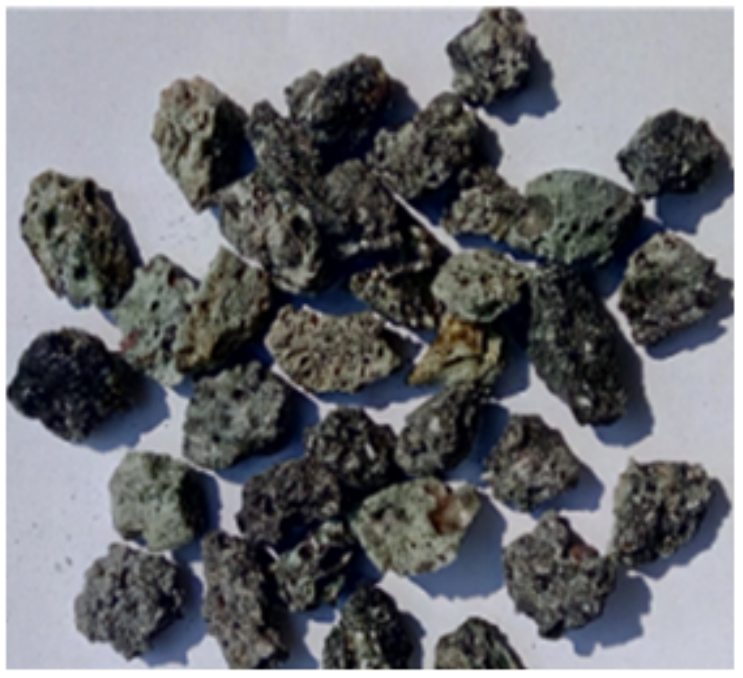

Figure 2

Palm oil clinker

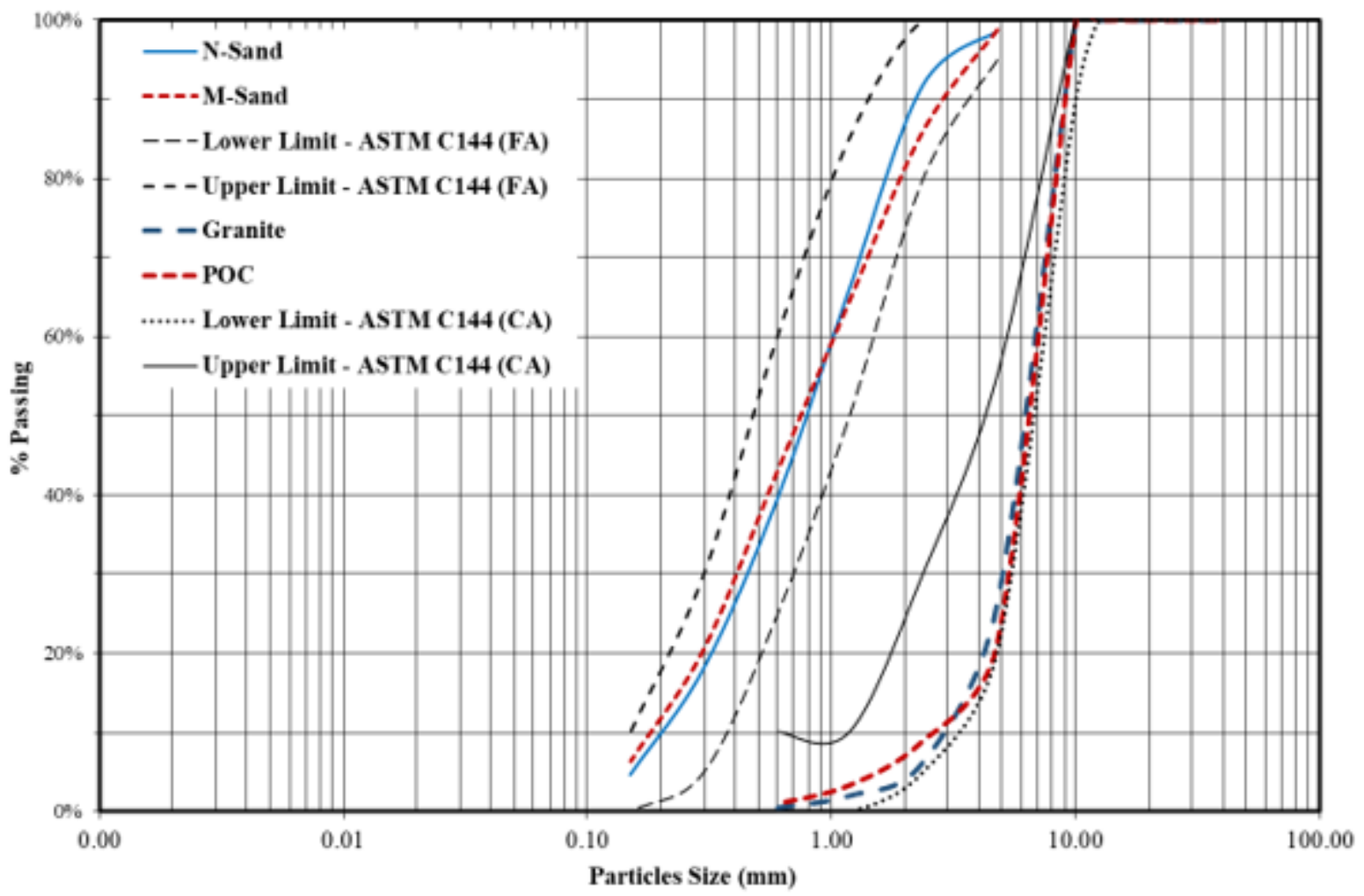

Figure 3

Grain size distribution of fine and coarse aggregates 

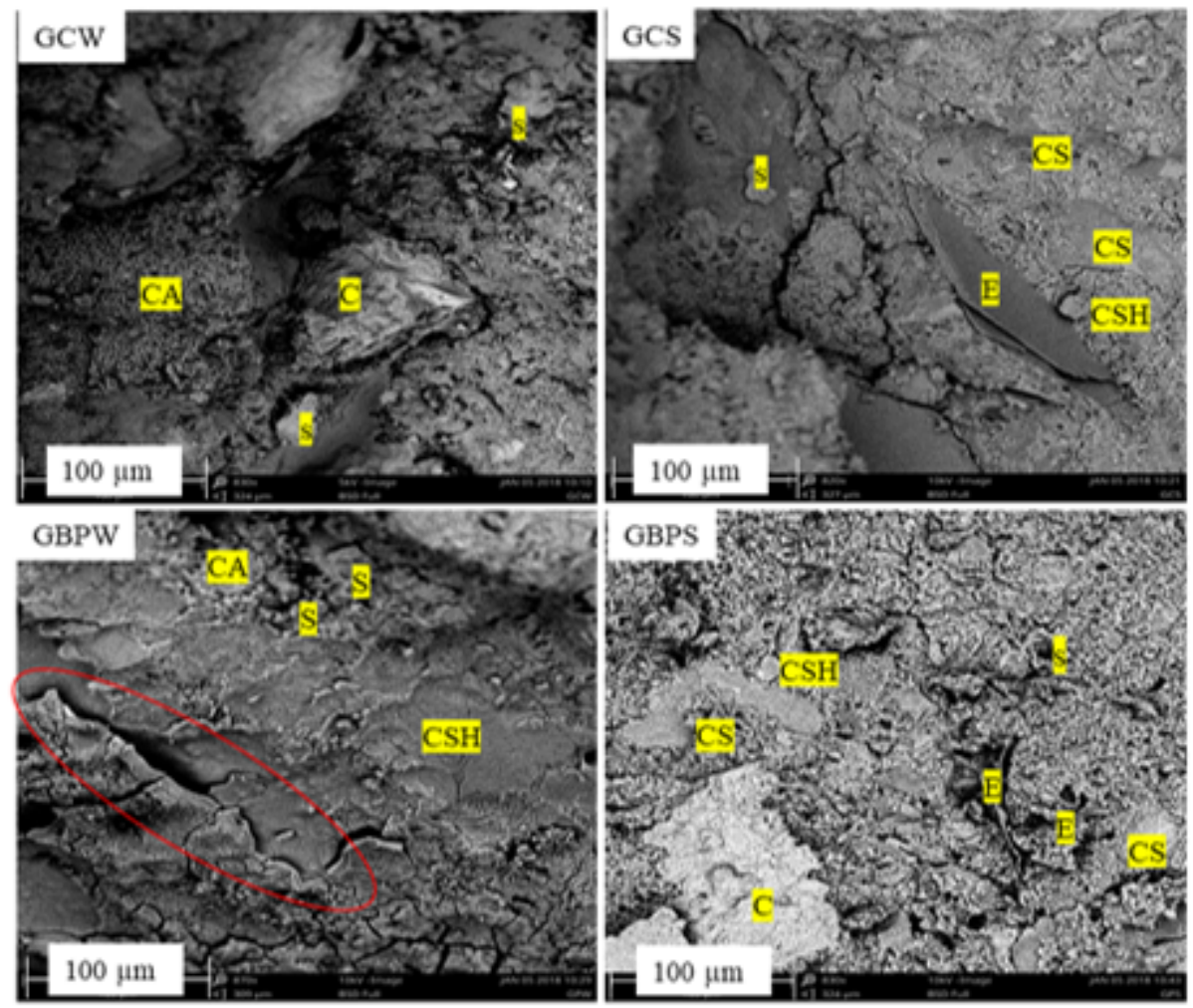

Figure 4

SEM images of masonry grouts

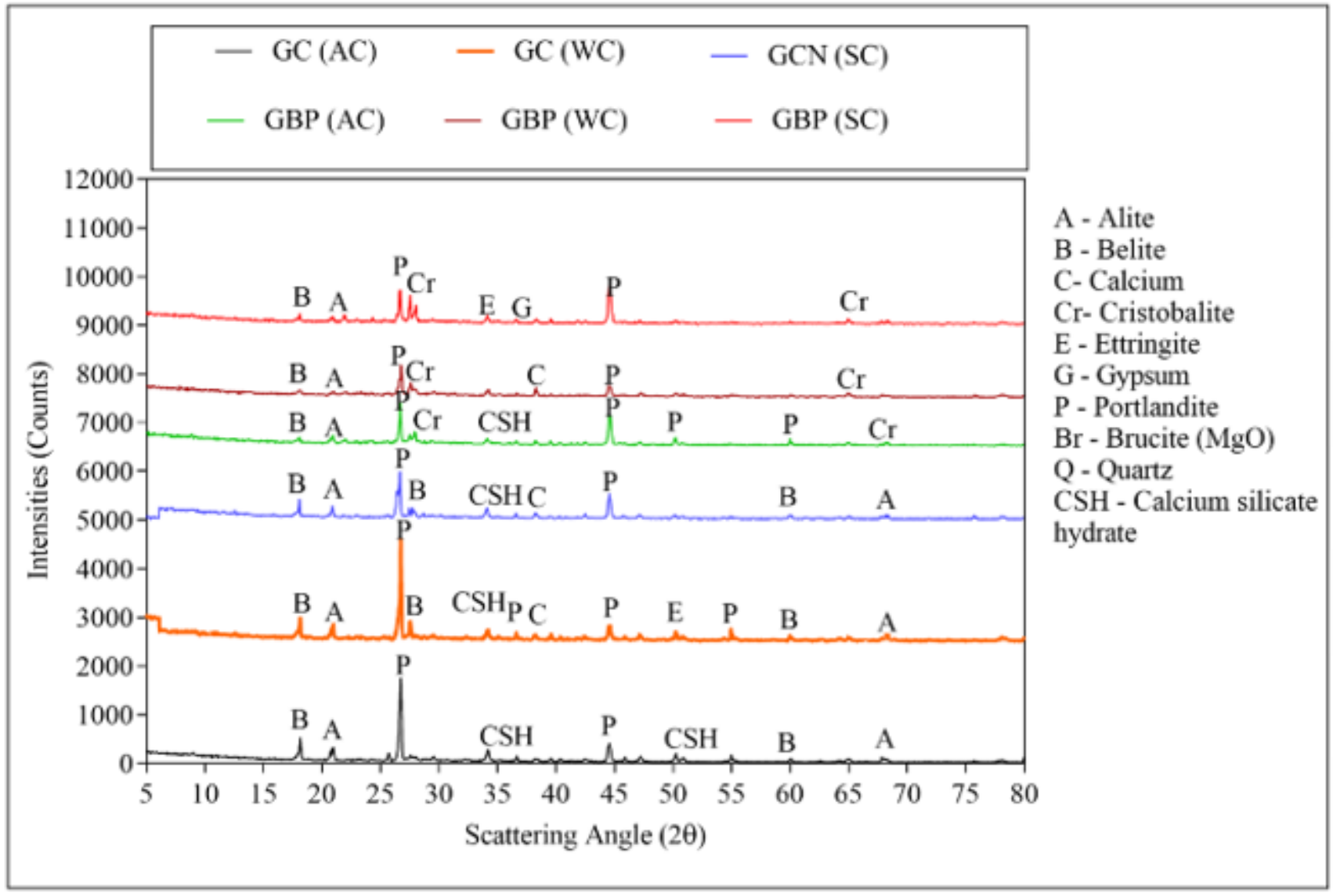


Figure 5

XRD patterns of masonry grout mixes at 28 days curing

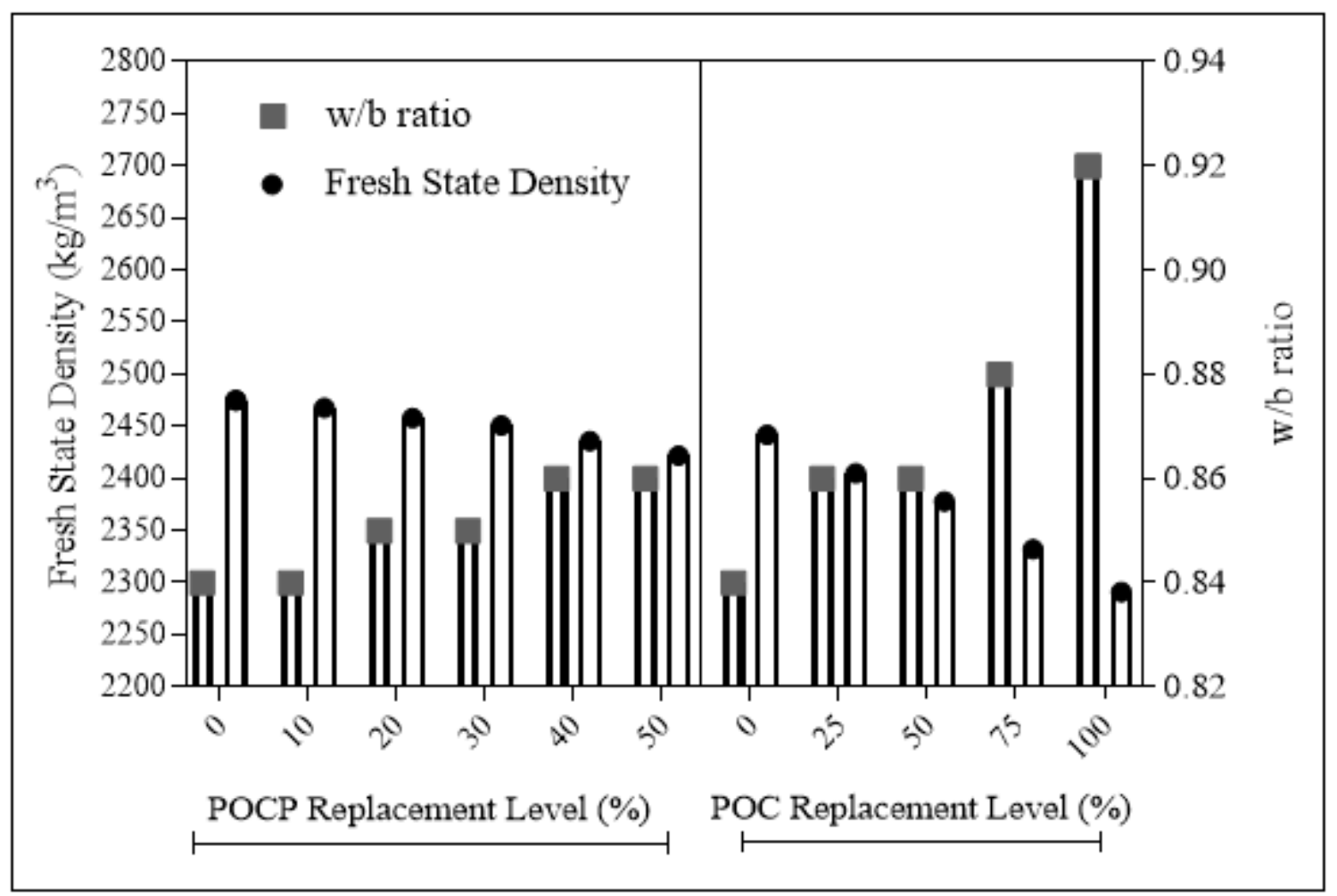

Figure 6

Fresh state density and w/b ratio as a function of POCP and POC levels

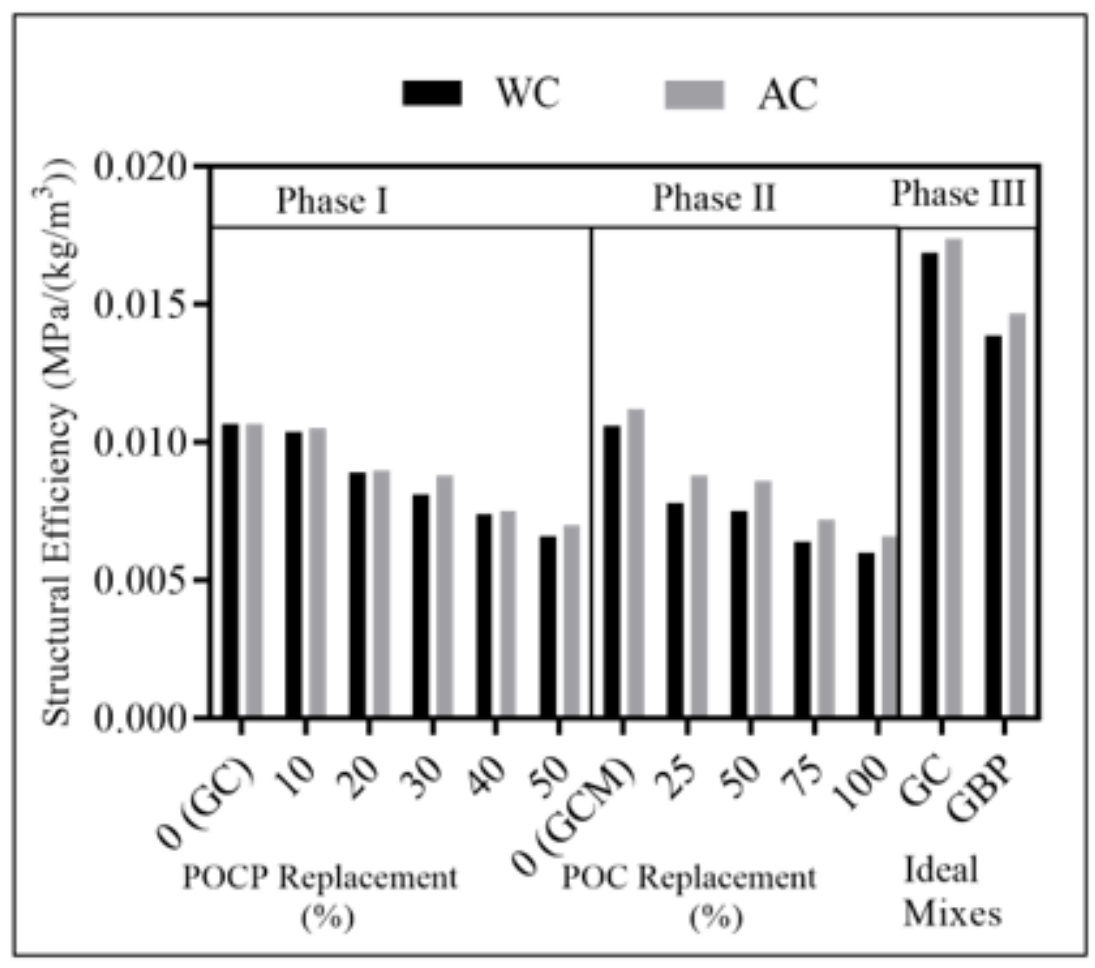


Figure 7

Structural efficiencies of masonry grouts

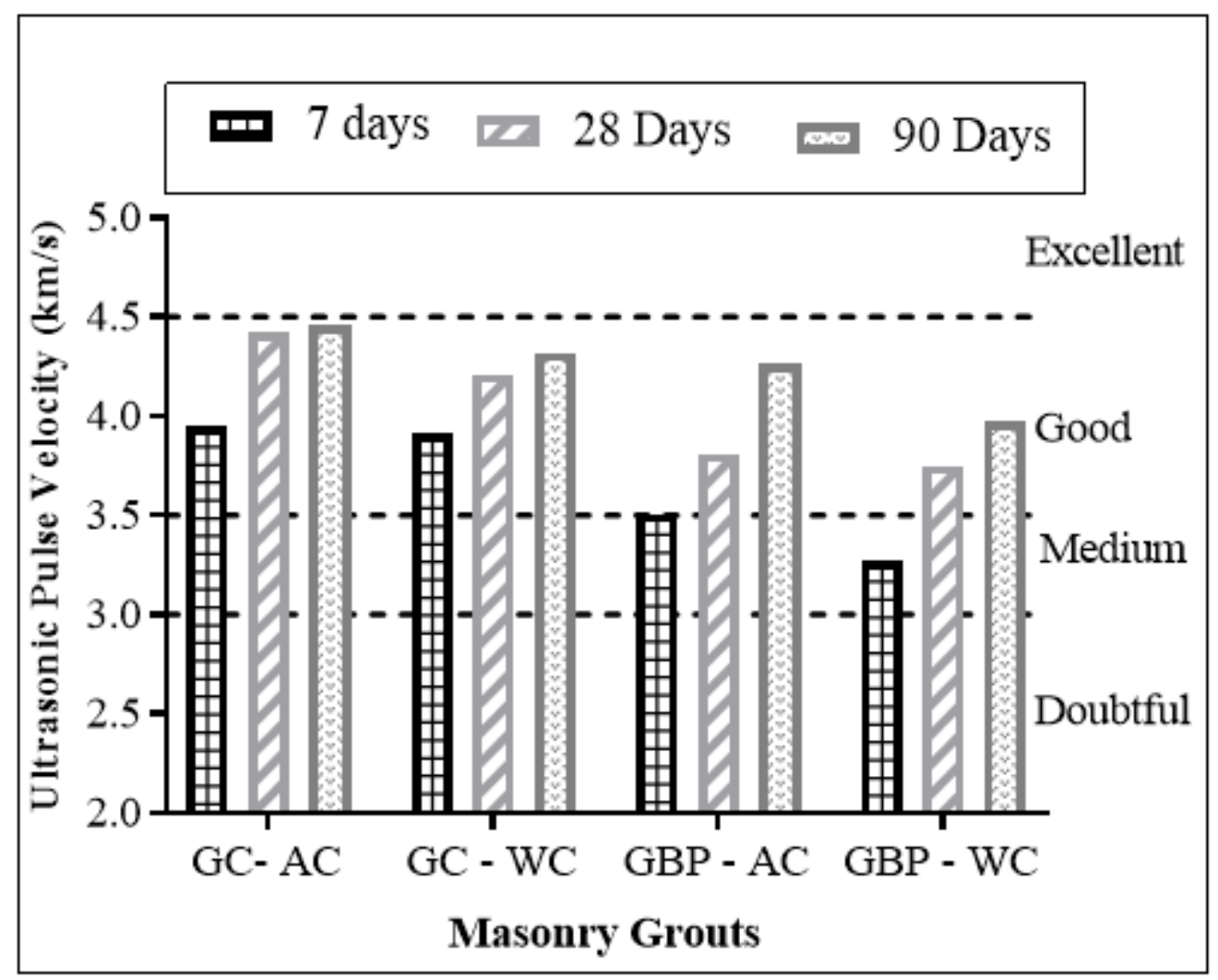

Figure 8

UPV values of GC and GBP mixes with different curing regimes

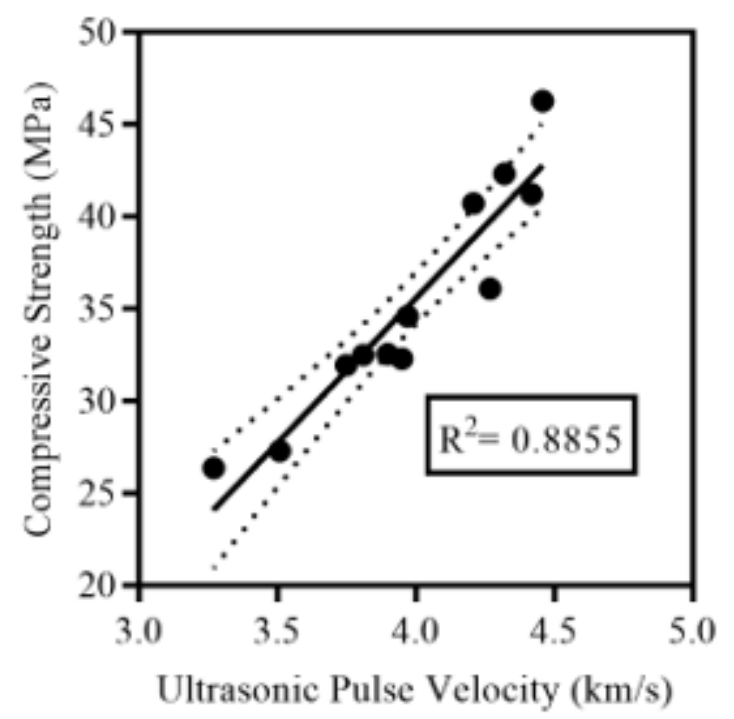

Figure 9 
Compressive strength and UPV relationship for phase III

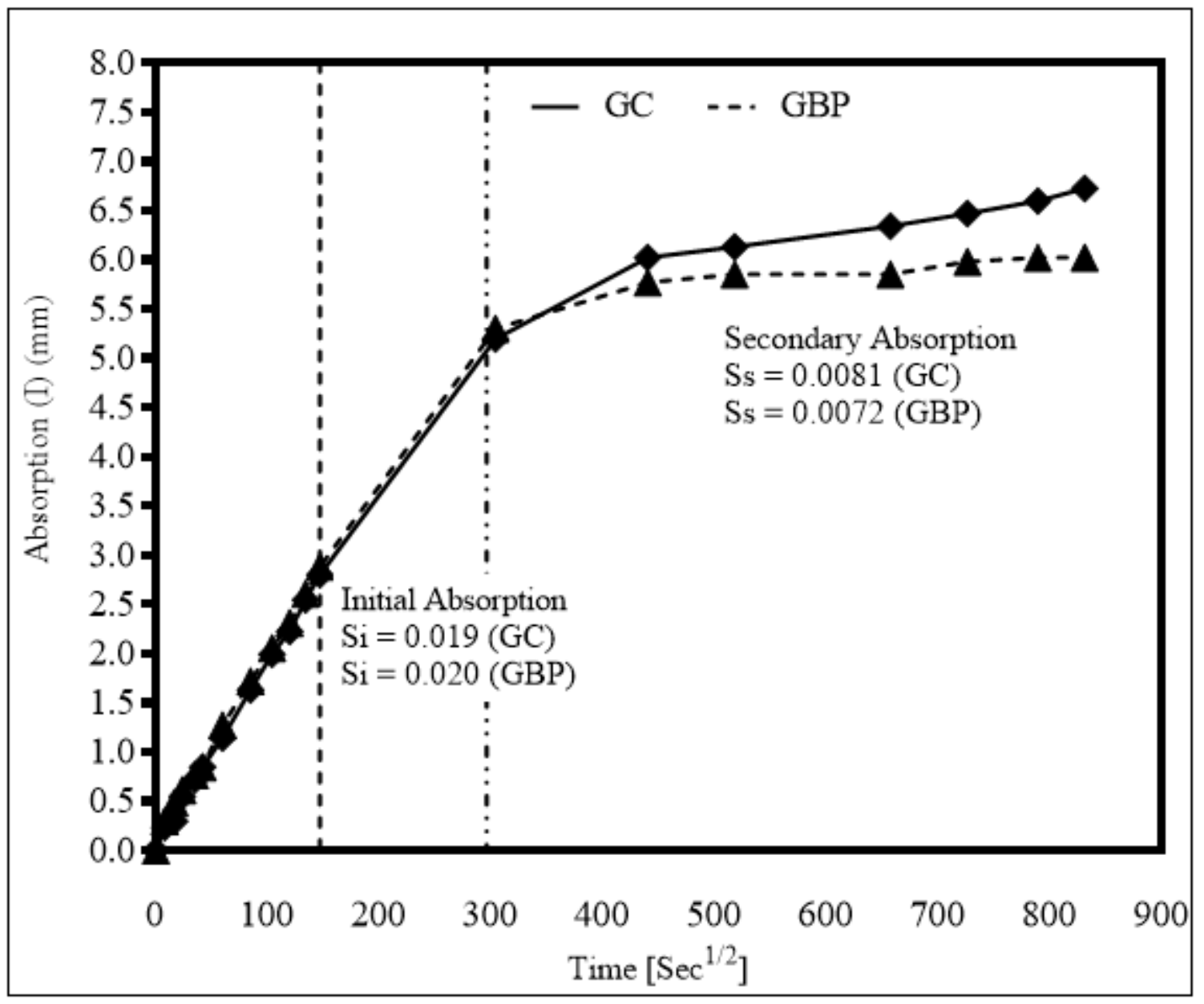

Figure 10

Initial and secondary rate of absorption of masonry grouts 


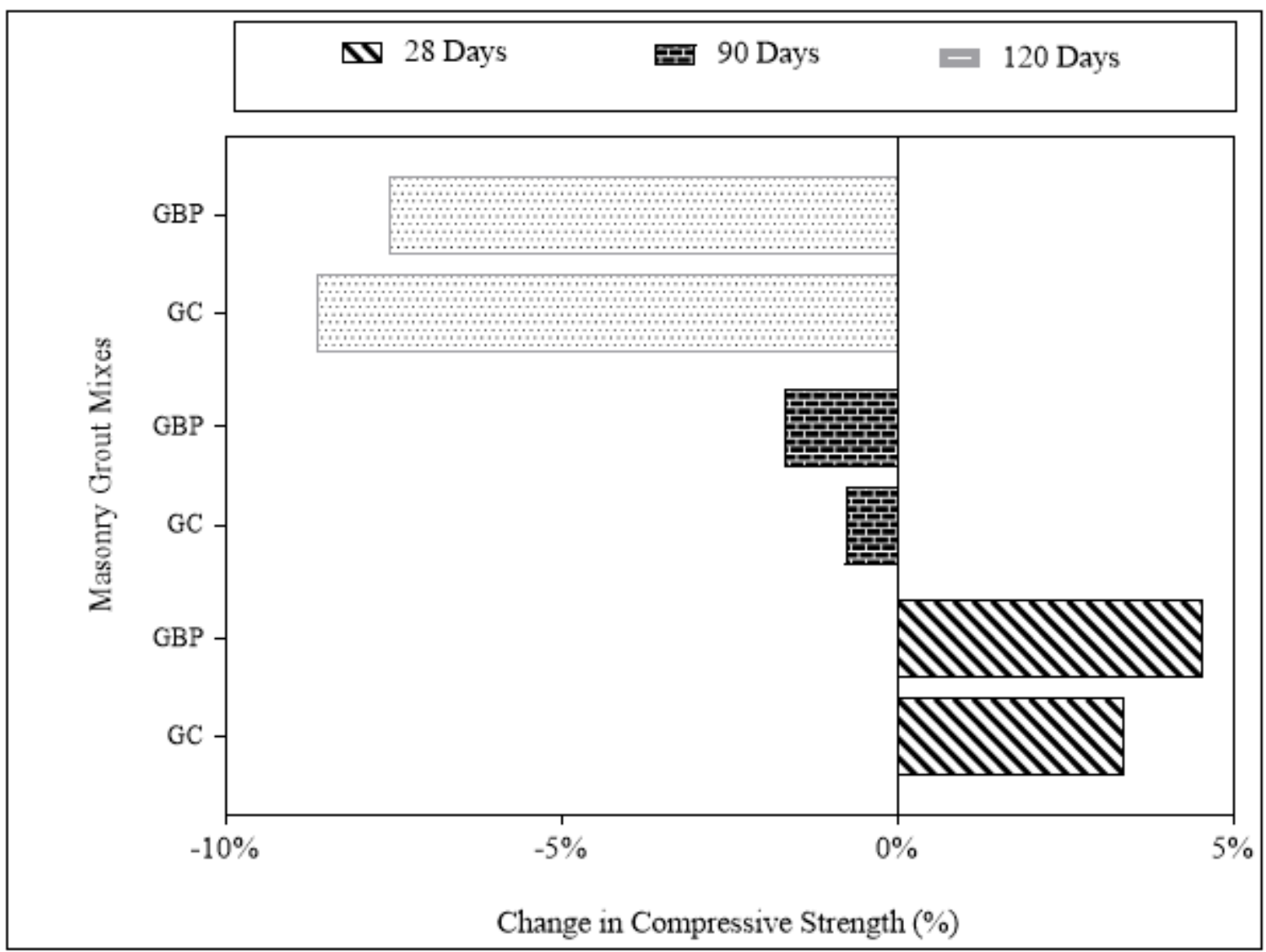

Figure 11

Change in compressive strength due to sulphate attack 


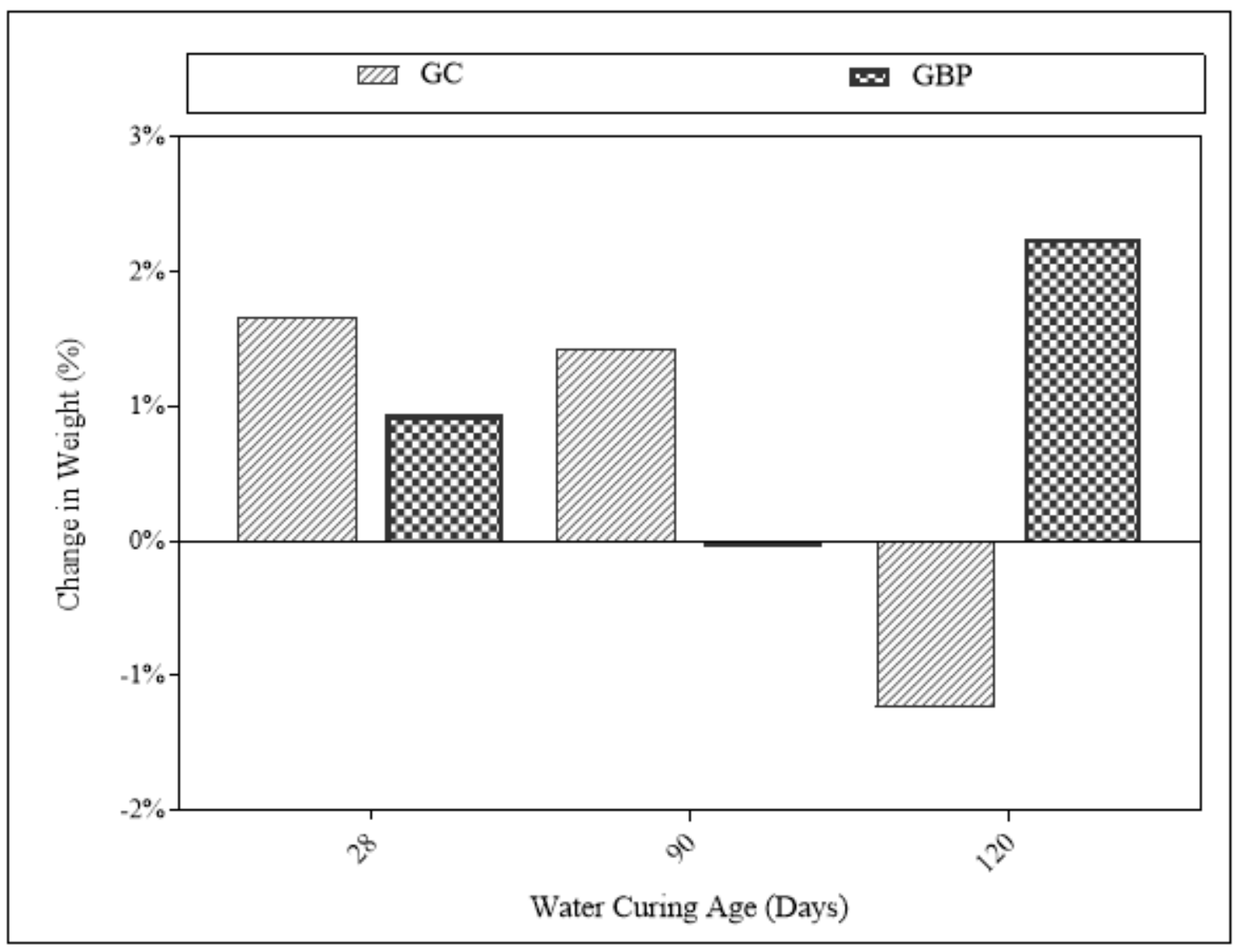

Figure 12

Change in weight due to sulphate attack 


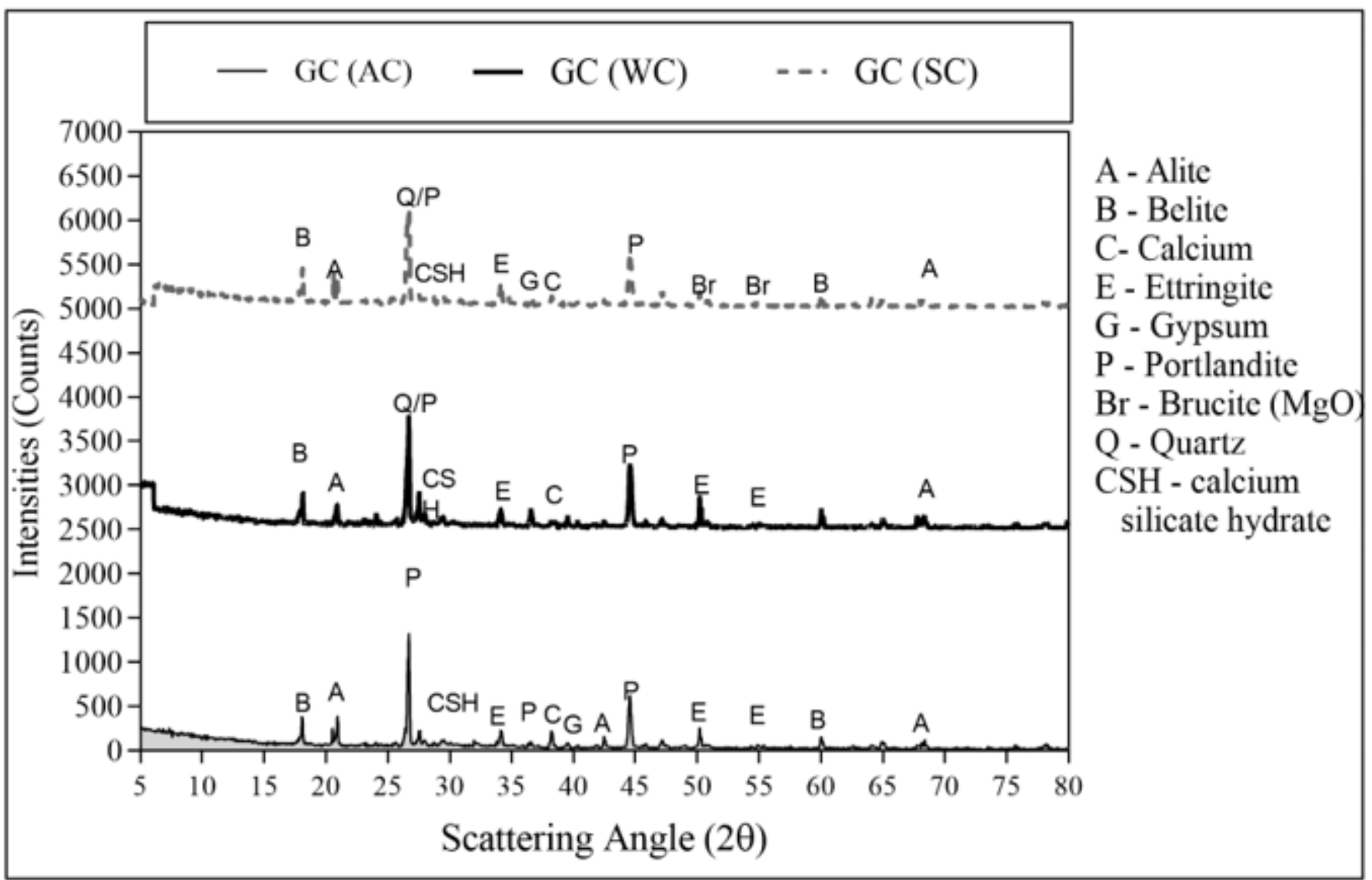

Figure 13

XRD patterns of Control mix at 120 days curing 


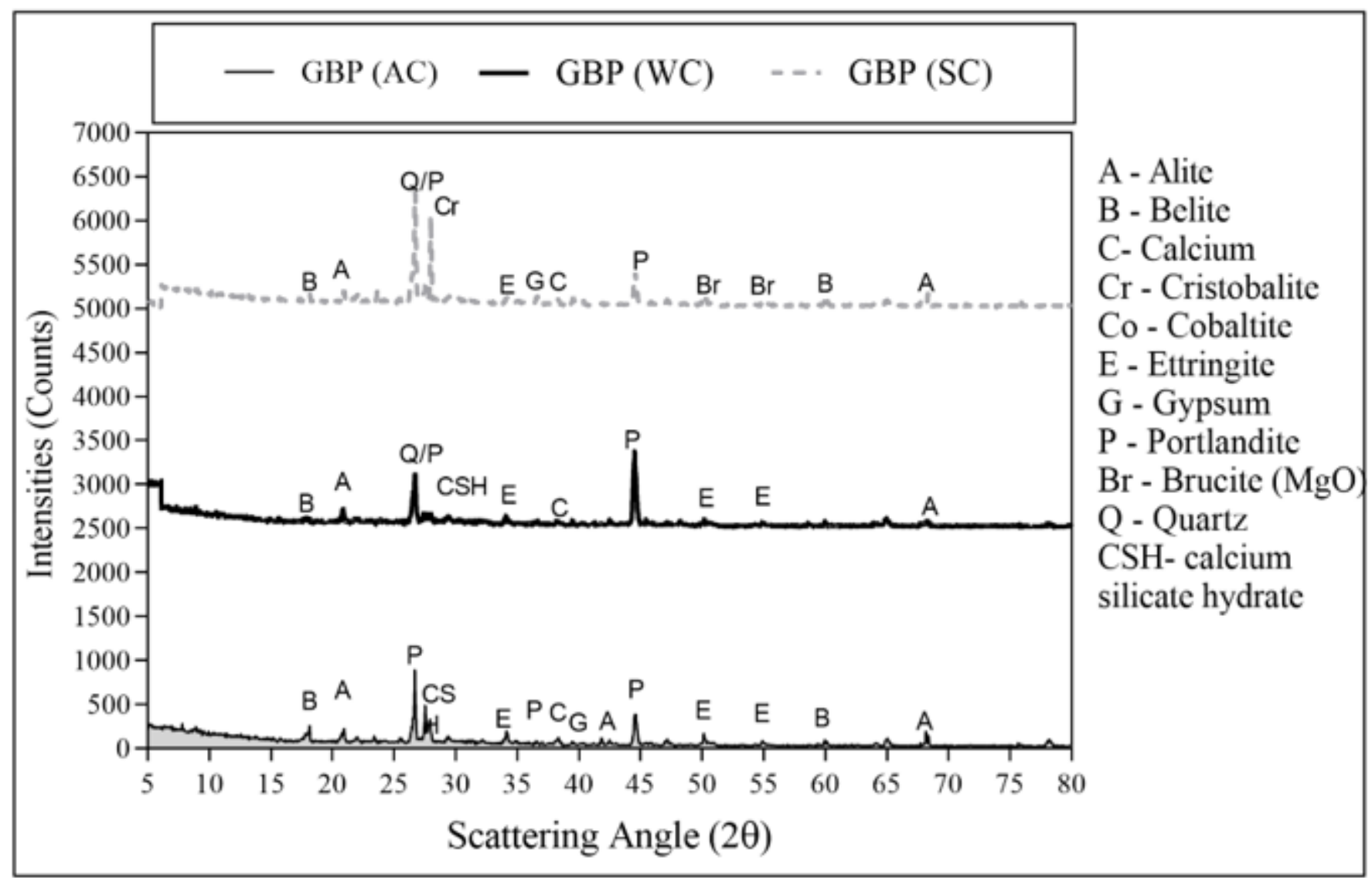

Figure 14

XRD patterns of Binary mix at 120 days curing
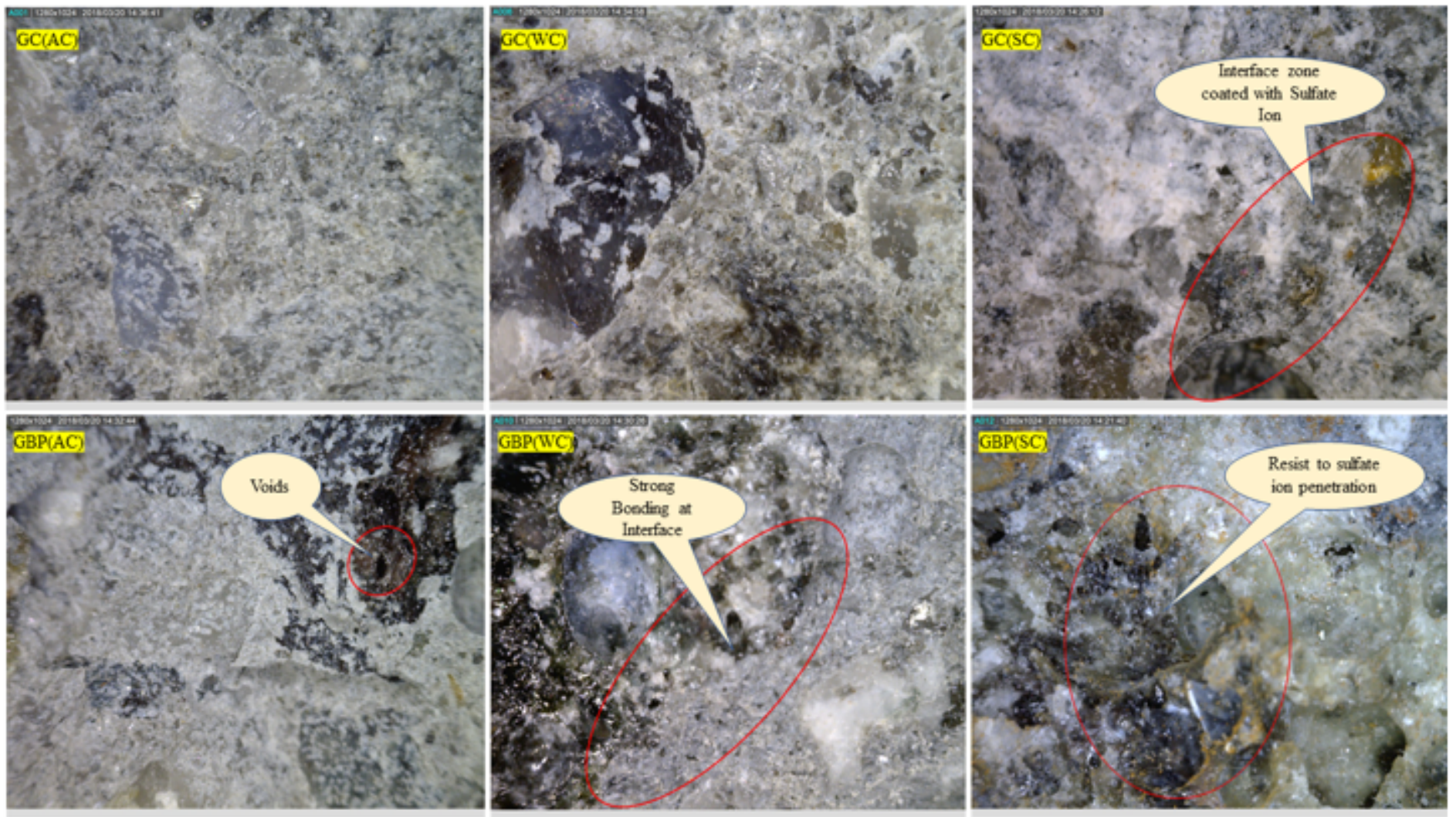
Figure 15

shows the microscopic images of grout mixes and the interfacial transition zone.

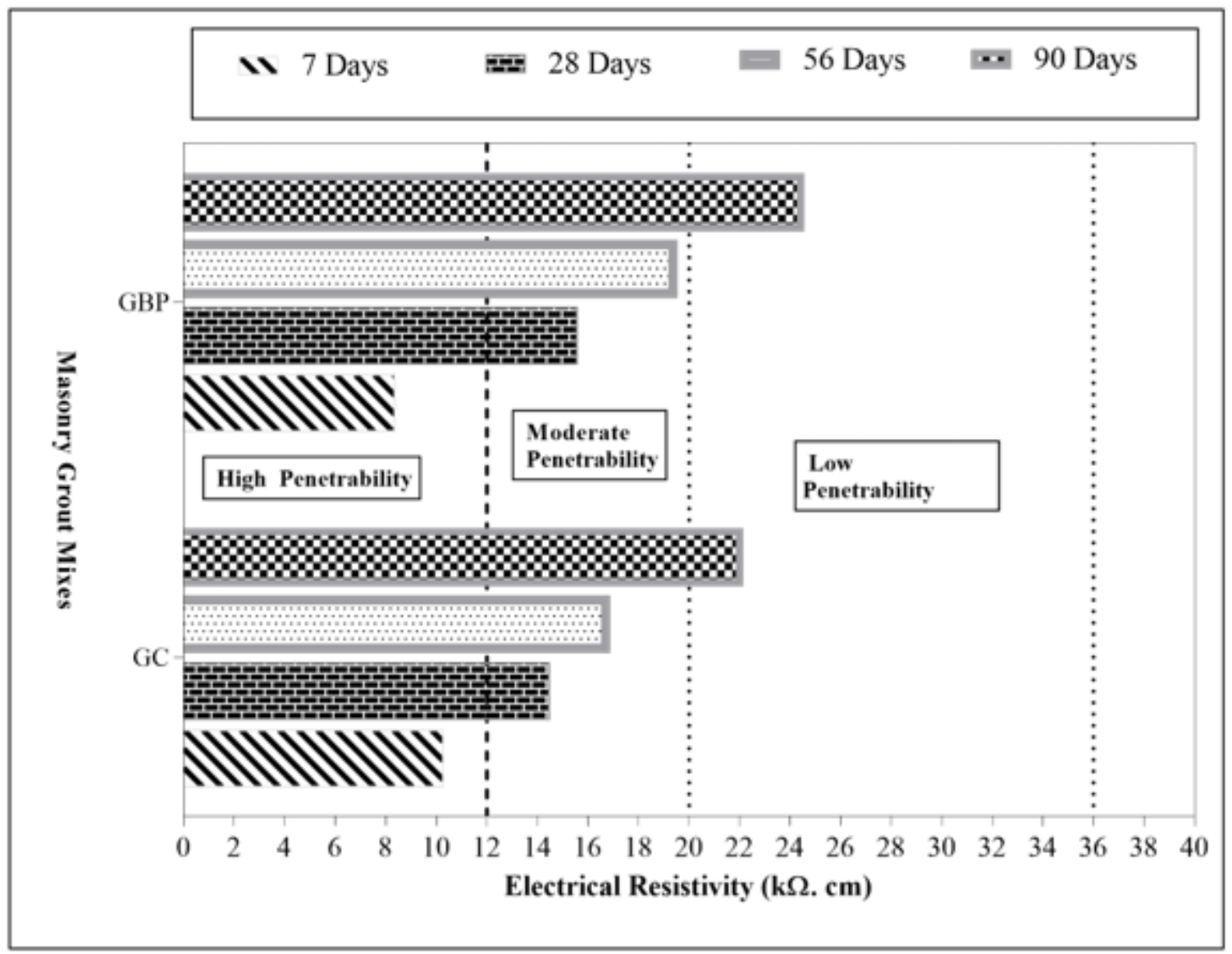

Figure 16

Electrical resistivity of grout mixes 


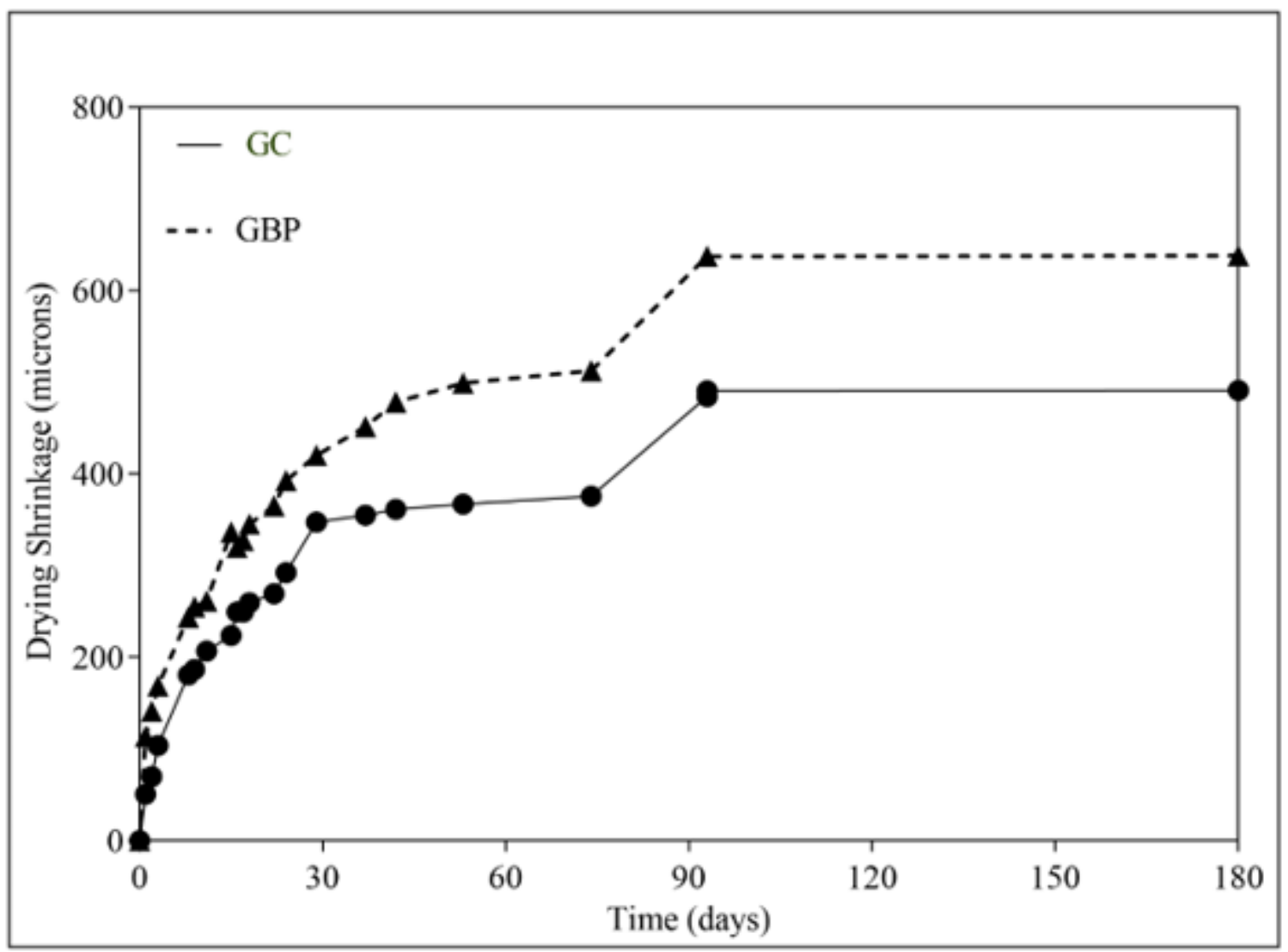

Figure 17

Drying shrinkage of the grouts 